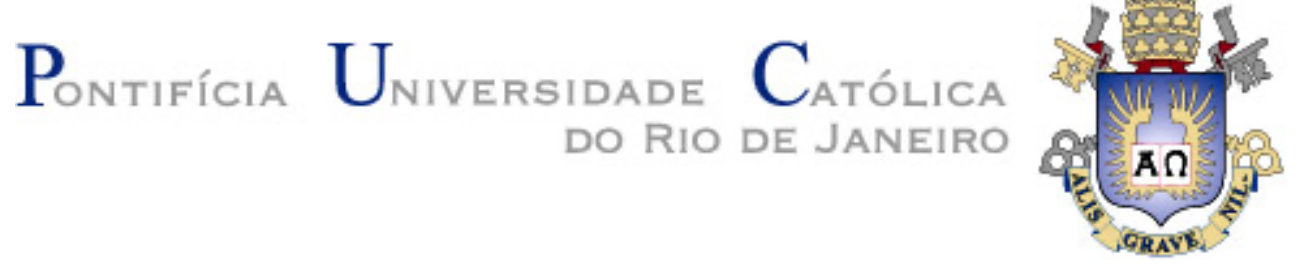

Paloma Louzada Bodanese

O SOFRIMENTO PSÍQUICO DA EQUIPE DE SAÚDE DE UTI NEONATAL

Dissertação de Mestrado

Dissertação apresentada como requisito parcial para obtenção do grau de Mestre pelo Programa de Pós-Graduação em Psicologia (Psicologia Clínica) do Departamento de Psicologia da PUC-Rio.

Orientadora: Prof ${ }^{a}$. Silvia Maria Abu-Jamra Zornig 


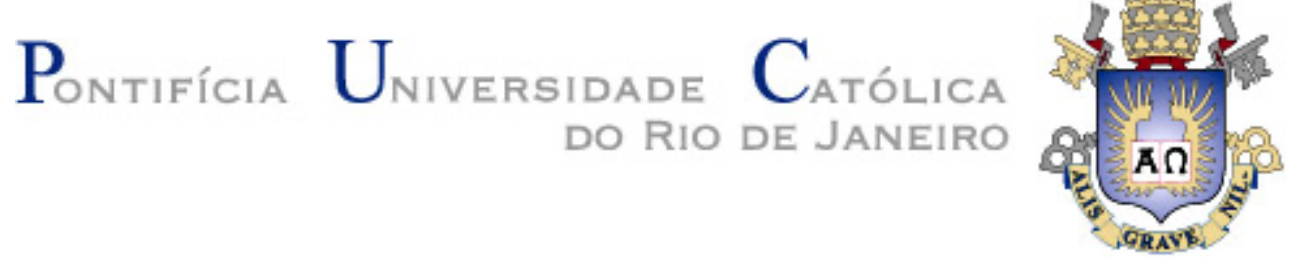

Paloma Louzada Bodanese

\section{O SOFRIMENTO PSÍQUICO DA EQUIPE DE SAÚDE DE UTI NEONATAL}

Dissertação apresentada como requisito parcial para obtenção do grau de Mestre pelo Programa de Pós-Graduação em Psicologia (Psicologia Clínica) da PUC-Rio. Aprovada pela Comissão Examinadora abaixo.

Profa. Silvia Maria Abu-Jamra Zornig Orientadora

Departamento de Psicologia - PUC-Rio

Profa. Issa Leal Damous Cursos de Especialização e Extensão - PUC-Rio

Profa. Sara Angela Kislanov Departamento de Psicologia - PUC-Rio

Rio de Janeiro, 04 de março de 2020. 
Todos os direitos reservados. É proibida a reprodução total ou parcial do trabalho sem autorização da universidade, da autora e da orientadora.

\section{Paloma Louzada Bodanese}

Graduou-se em Direito (2006) e em Psicologia (2015) pela PUC-Rio. Realizou estágio em moldes de residência na Perinatal Laranjeiras nos anos de 2015 a 2016 e 2017 a 2018. Atua na área de Psicologia Clínica com ênfase em adolescentes e adultos e dedica-se a pesquisas acadêmicas no campo da Psicologia e Psicanálise.

Ficha Catalográfica

Bodanese, Paloma Louzada

O sofrimento psíquico da equipe de saúde de UTI neonatal / Paloma Louzada Bodanese ; orientadora: Silvia Maria Abu-Jamra Zornig. - 2020.

77 f. ; $30 \mathrm{~cm}$

Dissertação (mestrado)-Pontifícia Universidade Católica do Rio de Janeiro, Departamento de Psicologia, 2020.

Inclui bibliografia

1. Psicologia - Teses. 2. Sofrimento psíquico. 3. Trauma. 4. Ambiente. 5. Identificação projetiva. 6. UTI neonatal. I. Zornig, Silvia Maria Abu-Jamra. II. Pontifícia Universidade Católica do Rio de Janeiro. Departamento de Psicologia. III. Título. 


\section{Agradecimentos}

À Silvia Zornig, por sua orientação ao longo da minha formação como psicóloga e pelo incentivo à realização do Mestrado.

Aos colegas do grupo de pesquisa coordenado pela professora Silvia Zornig, por dividirem o percurso comigo, pelas trocas e pelo apoio. Foi fundamental estarmos juntos.

À Helena Carneiro Aguiar, por ter me apresentado ao trabalho da Psicologia em UTI Neonatal e pela parceria que hoje se estende para além da UTI Neonatal.

À equipe de saúde de UTI Neonatal com quem tive o prazer de conviver por dois anos e meio.

Ao Sylvain Missonier e à Bérengère Beauquier-Maccotta, por terem me recebido no Hospital Necker-Enfants Malades em Paris.

À Sylvie Séguret, por ter me recebido em sua casa e por todo o material riquíssimo enviado, inspirando-me a estudar o sofrimento psíquico da equipe de saúde.

À minha mãe, por todo apoio e incentivo durante o percurso do Mestrado e também antes dele.

Ao Luiz Felipe, meu marido, pelo incentivo desde o início da minha escolha pela Psicologia. Por me escutar atentamente falar de autores e conceitos que são distantes de sua formação.

Ao meu filho, Rodrigo. Te amo.

O presente trabalho foi realizado com apoio da Coordenação de Aperfeiçoamento de Pessoal de Nível Superior - Brasil (CAPES) - Código de Financiamento 001 


\section{Resumo}

Bodanese, Paloma Louzada; Zornig, Silvia Maria Abu-Jamra (Orientadora). O sofrimento psíquico da equipe de saúde de UTI neonatal. Rio de Janeiro, 2020. 77p. Dissertação de Mestrado - Programa de Pós-Graduação em Psicologia (Psicologia Clínica), Pontifícia Universidade Católica do Rio de Janeiro.

Em UTI Neonatal estão internados bebês prematuros, sindrômicos ou com alguma malformação, havendo sempre um risco de morte. Diante das fragilidades de seus bebês e precipitados em um ambiente hostil onde há excesso de barulho, de luminosidade e de estímulos, os pais muitas vezes sentem-se angustiados, tristes e com raiva. Com os recursos psíquicos abalados e com sua capacidade de pensamento afetada, os pais podem lançar mão de mecanismos primitivos, como a identificação projetiva (Klein, 1946/1991a), para se defender. A equipe de saúde da UTI Neonatal, além de ser receptora das projeções parentais, necessita fazer face à constante ameaça de morte dos bebês. Acreditamos que diante desta ameça o ambiente da UTI Neonatal seria potencialmente traumático, inclusive para a equipe de saúde. O presente trabalho pretende, a partir da nossa experiência em UTI Neonatal, abordar o sofrimento psíquico a que está sujeito a equipe de saúde. Em razão do trabalho específico que desenvolvem, os membros da equipe de saúde podem chegar a um esgotamento emocional (Burnout). Pretendemos discutir como a equipe de saúde, para estar diante do sofrimento dos pais e dos bebês internados, necessita ela própria receber holding (Winnicott, 1975) e contenção (Bion, 1962) por parte da instituição de saúde. Acreditamos que os grupos de fala possuem importante função antitraumática para a manutenção da capacidade de pensar da equipe de saúde, para que possam continuar exercendo criativamente as suas atividades.

\section{Palavras-chave}

Sofrimento psíquico; trauma; ambiente; identificação projetiva; UTI Neonatal. 


\section{Abstract}

Bodanese, Paloma Louzada; Zornig, Silvia Maria Abu-Jamra (Advisor). Psychological suffering of the neonatal ICU health team. Rio de Janeiro, 2020. 77p. Dissertação de Mestrado - Programa de PósGraduação em Psicologia (Psicologia Clínica), Pontifícia Universidade Católica do Rio de Janeiro.

In Neonatal ICU, premature, syndromic or malformed babies are hospitalized and there is always a risk to life. Faced with the vulnerabilities of their babies and precipitated in a hostile environment where there is too much noise, light and stimulation, parents often feel distressed, sad and angry. With unsettled psychological resources and impaired thinking ability, parents can use primitive mechanisms, such as projective identification (Klein, 1946/1991a), to defend themselves. Neonatal ICU health staff, in addition to receiving parental projections, needs to address the constant threat of infant death. Due to these circumstances, we believe that the environment of the Neonatal ICU would be potentially traumatic, including for the health staff. The present work intends, based on our experience in Neonatal ICU, to address the psychological suffering to which the health team is subjected. Because of their specific work, health staff members can experience emotional burnout. We intend to discuss how the health staff, in order to face the suffering of parents and hospitalized babies, needs to receive holding (Winnicott, 1975) and containment (Bion, 1962) by the health institution. We believe that conversation groups have an important anti-traumatic function to maintain the health team's ability to think so that they can continue to perform their activities creatively.

\section{Keywords}

Psychological suffering; trauma; environment; projective identification; Neonatal ICU. 


\section{Sumário}

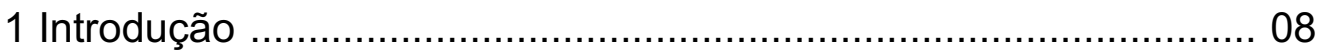

$2 \mathrm{O}$ ambiente da UTI Neonatal ............................................... 13

$2.1 \mathrm{O}$ fantasma da morte em UTI Neonatal ................................... 23

2.2 Trauma e denegação da morte ....................................... 28

3 Identificação projetiva no ambiente da UTI Neonatal ................... 36

3.1 Vinheta clínica: morte e identificação projetiva ......................... 47

4 Funções antitraumáticas na UTI Neonatal ................................ 55

4.1 Pesadelos relacionados ao serviço .................................... 61

4.2 Caso Sara: uma narratividade coconstruída ......................... 65

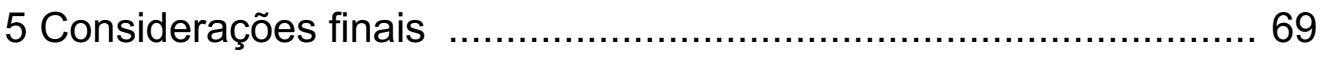

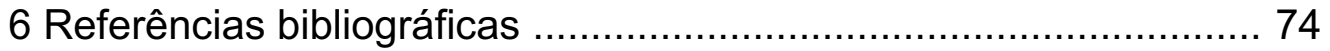




\section{Introdução}

A nossa experiência como psicóloga em uma Unidade de Terapia Intensiva Neonatal (UTI Neonatal) de uma maternidade particular do Rio de Janeiro, permitiu-nos testemunhar e participar de situações delicadas no que se refere ao nascimento de bebês prematuros, com sequelas do parto ou ainda com síndromes genéticas.

Ao longo do período em que atuamos na UTI Neonatal, chamou-nos atenção a rotina intensa e a grande carga emocional a que está submetida a equipe de saúde, composta por médicos, enfermeiros, técnicos de enfermagem, fisioterapeutas, fonoaudiólogas e psicólogas. Estudos apontam que, em razão do trabalho específico que desenvolve, a equipe de saúde de UTI Neonatal vive em situação de estresse constante, muitas vezes podendo chegar a um esgotamento emocional (burnout). Tal esgotamento emocional traz inúmeras repercussões, tais como: riscos depressivos, afastamento do trabalho, conflitos entre a equipe e entre a equipe e os pais dos bebês internados (Fogaça, Carvalho, Cítero \& NogueiraMartins, 2008; Monteiro, 2012; Moraes \& Granato, 2014).

Neste ambiente, há tensão e senso de urgência no ar, pois é ali que dois eventos importantes da vida são confrontados diariamente: nascimento e morte. Trabalha-se intensamente para a manutenção da vida dos bebês, mas, sem pedir licença, apesar do avanço da medicina e de toda a tecnologia, a morte se impõe. Neste ambiente em que a morte é uma ameaça constante, questionamos: como é possível manter-se psiquicamente vivo?

O estudo proposto é relevante para compreender os efeitos da contínua exposição da equipe de saúde, confrontada diariamente com o sofrimento dos pais e dos bebês internados em UTI Neonatal, a eventos potencialmente traumáticos e os mecanismos de defesa dos quais lançam mão para se proteger.

Acreditamos que, muitas vezes, o sofrimento da equipe de saúde não é reconhecido pelo ambiente. O presente estudo pretende dar lugar a esse sofrimento e pensar quais as possibilidades de acolhimento da equipe. Além disso, acreditamos que a compreensão do que se passa com os profissionais de saúde 
poderá repercutir positivamente nos conflitos que surgem entre os membros da equipe e entre a equipe e os pais dos bebês internados.

Com o intuito de responder a pergunta feita acima - "como manter-se psiquicamente vivo no ambiente de UTI Neonatal?" -, iniciaremos o presente trabalho descrevendo o ambiente de UTI Neonatal. Um ambiente com excesso de ruído, luminosidade, monitores, cheiros, tecnologia e tensão por conta da fragilidade dos bebês internados.

A equipe de saúde de UTI Neonatal tem consciência que a sobrevivência dos bebês depende dos seus gestos, acarretando sobrecarga ainda maior para os cuidadores. Neste ambiente, trabalha-se para salvar a vida dos bebês, mas o fantasma da morte parece estar à espreita. E quando, apesar dos esforços, um bebê morre? Qual o impacto dessa morte na equipe de saúde? Como continuar o plantão cuidando dos demais bebês?

A morte de um bebê é da ordem do inominável. Quando um filho perde os pais, torna-se órfão, mas não há palavras para nomear a morte de um filho. A morte de um bebê representa uma inversão da ordem natural da vida: nascemos, vivemos, morremos, podendo ser extremamente tocante para a equipe de saúde também quando morre um bebê no serviço. A equipe é composta por sujeitos, que possuem suas histórias pessoais, e são esses sujeitos que cuidam dos bebês. Além disso, a morte de um bebê pode abalar a onipotência da equipe, que está ali para salvá-los.

Para que a equipe de saúde desempenhe bem o seu papel em UTI Neonatal, algumas defesas são necessárias, e ilustramos essa situação recorrendo ao exemplo do campo cirúrgico, que esconde o bebê, deixando aparente apenas a área a ser manipulada. Ao puncionar um bebê é necessário, momentaneamente, esquecer que se trata de um bebê. No entanto, o excesso de defesas pode ser potencialmente danoso para a equipe de saúde, provocando isolamento dos membros da equipe, conflitos entre a equipe, adoecimento, afastamento do trabalho e burnout. Recorremos às teorias de Winnicott (1975; Davis, 1982) e Ferenczi (1933/2011) para pensar o ambiente da UTI Neonatal como potencialmente traumático para a equipe de saúde.

No capítulo seguinte, expomos a ideia de que no ambiente de UTI Neonatal sentimentos como raiva, tristeza, ódio e mecanismos muito arcaicos como clivagem e identificação projetiva aparecem de forma muito explícita. 
Utilizamos o conceito de identificação projetiva para pensar as vicissitudes e os impasses que surgem entre cuidadores e pais.

Iniciamos o estudo sobre identificação projetiva a partir da teoria kleniana (1946/1991a), compreendendo a projeção como a evacuação das partes ruins do eu para, em seguida, ampliar este conceito com o apoio da teoria bioniana (1962). A metáfora continente-conteúdo de Bion (1962) serviu de base para compreender a identificação projetiva como modalidade de comunicação primitiva. Ao terem seu bebê internado em UTI Neonatal, os pais podem viver um momento de caos psíquico e ter a sua capacidade de pensar afetada. Assim, emocionalmente abalados, os pais projetariam um conteúdo difícil deles lidarem na equipecontinente, receptora da identificação projetiva paterna. A equipe de saúde, através da sua capacidade onírica (rêverie), receberia e transformaria os elementos beta (elementos brutos), característicos da identificação projetiva, em elementos alfa (Bion, 1962).

A experiência de ter seu bebê internado provocaria um congelamento psíquico e, através dos mecanismos de identificação projetiva, a equipe metabolizaria os sentimentos em algo mais palatável, devolvendo-os aos pais para reintrojeção. Nesse sentido, o processamento da experiência emocional seria feito pela equipe de saúde, que, através da interação com os pais, os disponibilizaria para reintrojeção.

A capacidade de a equipe de saúde manejar a identificação projetiva dos pais é fundamental e trouxemos uma vinheta clínica para ilustrar e refletir sobre as experiências vividas em UTI Neonatal. Para que a equipe de saúde seja capaz de lidar com os sentimentos hostis e de agressividade dos pais dos bebês internados, é importante que seja capaz de lidar com seus próprios sentimentos hostis. Os sentimentos da equipe de saúde em relação às experiências vivenciadas na UTI Neonatal também precisam ser digeridos. E como digeri-los em meio a uma rotina intensa, cuidando de bebês frágeis, com o fantasma da morte que assombra?

É importante ressaltar que seria possível estudar a identificação projetiva tanto como a equipe projetando seus conteúdos nos pais, como os pais projetando seus conteúdos na equipe de saúde. Ambas as situações são importantes, no entanto, por uma limitação de tempo, optamos por nos dedicar ao estudo das projeções parentais na equipe de saúde, sendo a equipe receptora das projeções. 
Para finalizar, no último capítulo, considerando o ambiente da UTI Neonatal potencialmente traumático para a equipe de saúde, refletimos sobre a função antitraumática a ser colocada em prática no e pelo ambiente da UTI Neonatal para que a morte psíquica não prevaleça sobre a morte do corpo. A função antitraumática permite que o sujeito lide com as agonias impensáveis, promovendo estabilidade mental e ligações importantes para a saúde mental do cuidador.

Utilizamos os conceitos de holding (Winnicott, 1975), continência e rêverie (Bion, 1962) para pensar três exemplos de situações antitraumáticas: os grupos de fala, os pesadelos relatados pela equipe de saúde e o filme "Sara, une narrativité collégiale: l'éthique au quotidien dans un service de réanimation pédiatrique" ("Sara, uma narratividade coconstruída: a ética no quotidiano de um serviço de reanimação pediátrica", tradução nossa), produzido por Séguret e dirigido por Jeudon (2016).

Defendemos a ideia de que os grupos de fala compostos por membros da equipe de saúde da UTI Neonatal podem ser importantes recursos na integração dos excessos vividos no serviço. Diante do desamparo que o cuidador pode ficar quando morre um bebê, por exemplo, ter um espaço de pensar e para compartilhar a sua experiência com os demais pode ser apaziguador e ajudar a dar sentido ao que se viveu. A capacidade de sonhar em grupo permite à equipe metabolizar os acontecimentos dolorosos e inevitáveis a que estamos sujeitos, especialmente quando se trabalha em UTI Neonatal.

Demos destaque aos pesadelos relacionados ao serviço de reanimação pediátrica e relatados pelos cuidadores à Seguret $(2012,2013)$. Contar o pesadelo para a psicóloga do serviço provocava um sentimento de apaziguamento. Posteriormente foi solicitado que os cuidadores escrevessem seus pesadelos com o intuito de preservar os termos. Ambas as situações de relatar o pesadelo e de escrever o pesadelo permitiram um distanciamento inicial, contribuindo para a elaboração do conteúdo sonhado.

Acreditamos que os pesadelos contados pelos cuidadores têm função de abertura para a narratividade e, por isso, só faziam sentido sendo compartilhados com a psicóloga do serviço e com os outros membros da equipe de saúde.

Por fim, nos debruçamos sobre o filme Sara. A morte da menina Sara, portadora de uma patologia rara e complexa, mobilizou enormemente a equipe de 
saúde. Foi necessário realizar uma reunião entre os membros da equipe que estavam de plantão e os demais membros que chegavam para a troca de turno. Séguret lamentou não ter gravado a reunião e foi assim que surgiu o filme. A reunião de equipe, a produção e a reprodução do filme tiveram função de conter e de transformar os fortes sentimentos experimentados pelos cuidadores. 


\section{2 \\ Ambiente da UTI Neonatal}

Na maternidade em que trabalhamos, a UTI Neonatal divide-se em UTI I, UTI II e UTI III. A UTI I é composta por 16 leitos, sendo praticamente todos os bebês internados em seu serviço, onde recebem os primeiros cuidados. Trata-se da unidade mais intensiva, em que os bebês de maior risco estão acomodados. Os casos mais graves permanecem ali pelo tempo que for necessário. Diante disso, é o setor mais barulhento, pois há mais monitores, mais bombas infusoras, mais alarmes. A gravidade dos bebês pode ser avaliada pelo número de equipamentos ao redor de sua incubadora. A tensão é quase palpável e pode ser percebida na atmosfera da UTI, mas também na postura e fisionomia da equipe. Acreditamos que as palavras utilizadas por Mathelin (1999) para descrever o seu serviço, ajudam-nos a descrever o ambiente da UTI I no nosso serviço:

\footnotetext{
Naquela manhã eu reconheci imediatamente, entrando no serviço de neonatologia onde trabalho como psicanalista, a atmosfera das grandes urgências. Conhecemos bem esse ambiente particularmente pesado, ele é a marca ao mesmo tempo de uma extrema tensão e de uma grande calma. Sentimento de pânico, jamais. Nenhuma precipitação. Quanto mais preciosos os minutos, mais a equipe parece alheia ao tempo. Sentimos o medo na troca de olhares; nesse controle artificial fabricado pela experiência. (Mathelin, 1999, p. 61)
}

À medida que os bebês vão evoluindo, eles vão sendo "promovidos", como dizem os membros da equipe de saúde e, também, os pais dos bebês. Essa promoção tem a ver com a estabilidade da saúde do bebê. Primeiramente, os bebês são "promovidos" para os últimos leitos da UTI I e depois para a UTI II, uma unidade de cuidados intermediários, que funciona como uma unidade semiintensiva, parecendo-se mais com um berçário.

A UTI II é composta por 20 leitos. Quando o bebê atinge o peso aproximado de $1.700 \mathrm{~g}$, ele poderá ir para o berço de acrílico. A ida do bebê para o berço é o momento em que os pais passam a ter livre acesso aos seus filhos. Se, quando o bebê estava na incubadora, os pais dependiam da equipe de saúde para colocar seu bebê no colo, a partir do momento em que o bebê está no berço, os pais podem pegá-lo no colo, trocar a fralda, trocar a roupa do bebê, dar o banho.

A ida do bebê da UTI I para a UTI II nem sempre é sentida, logo de início, como positiva pelos pais. Muitos estranham o relativo "silêncio" e até a 
fisionomia da equipe menos tensa. Em casos de internações prolongadas, alguns pais chegam a levar móbiles para colocar em cima dos berços de acrílico. A UTI III é fisicamente uma extensão da UTI II e é utilizada quando algum bebê, colonizado por determinada bactéria, precisa ficar isolado dos demais bebês.

Muitos são os estudos que se dedicam a pensar este ambiente de UTI Neonatal a partir do ponto de vista do bebê e de seus pais, no tocante às questões relacionadas à constituição subjetiva, à vinculação pais-bebê prematuros, dentre outros temas extremamente relevantes e pertinentes. As autoras Zornig, Morsch e Braga (2004) destacam que há algo de potencialmente traumático para os pais e o bebê quando se trata de nascimento prematuro:

[...] a situação de prematuridade pode ser traumática para os pais e para o bebê pela própria descontinuidade temporal introduzida pelo parto antecipado (prematuro), parto que interrompe o processo de construção do bebê imaginário e confronta os pais com o real orgânico do bebê em uma situação - UTI Neonatal - em que a temporalidade é urgente, premente, relacionada à sobrevivência do bebê e não à qualidade de seus cuidados. (Zornig, Morsch \& Braga, 2004, p. 139)

No entanto, ainda que sejam fundamentais tais estudos sobre a constituição psíquica de bebês prematuros e sobre a relação pais-bebês em UTI Neonatal, optamos por aprofundar nossos estudos em relação ao sofrimento psíquico da equipe de saúde da UTI Neonatal, tema que acreditamos ser também muito relevante. Este tema vem sendo estudado já há algum tempo por psicólogos e psicanalistas na França (Séguret, 2012, 2013; Mathelin, 1999; Soubieux, 2013).

Para compreender as questões relacionadas à equipe de saúde, é importante ter em mente o que está se passando com o bebê e seus pais. Como o serviço da UTI Neonatal está organizado em função do atendimento do bebê, iremos iniciar a nossa descrição do ambiente a partir do que está acontecendo com o bebê e seus pais nesse momento delicado do nascimento. Em seguida, então, daremos continuidade às questões da equipe de saúde.

Tendo como base o pensamento winicottiano, o nascimento em si não é considerado traumático, pois a reação do bebê é temporária a esta transição da vida intrauterina para a vida extrauterina, em função de o bebê, logo após o nascimento, encontrar um outro em estado de preocupação materna primária (Winiccott, 1956/2000b), capaz de se identificar às suas necessidades.

Os bebês, que em uma gestação a termo ainda estariam no ventre materno aquecidos, alimentados e protegidos, na UTI Neonatal são separados 
prematuramente de suas mães e expostos a um ambiente com excessos de estímulos: apitos, barulhos, luzes, procedimentos invasivos, sensores de oxigenação e de batimento cardíaco, sondas de alimentação. O nascimento prematuro provoca uma descontinuidade temporal dupla para o bebê. Primeiramente, o nascimento prematuro e a consequente ida do bebê para a UTI Neonatal dificulta o início dos cuidados parentais. Em segundo lugar, exige que o bebê se adapte às condições ambientais, justamente o contrário do que Winnicott propõe ao falar de preocupação materna primária, período de grande sensibilidade afetiva em que a mãe-ambiente consegue se identificar e atender às necessidades do bebê. Na UTI Neonatal, o bebê terá que "reagir" ao invés de "existir" (Zornig, Morsch \& Braga, 2004).

Os pais são lançados, juntamente com seu bebê, nesse ambiente desconhecido em que vida e morte convivem lado a lado. Tudo o que havia sido sonhado por esses pais, precisará ser revisto, mas em um tempo urgente. Nos atendimentos iniciais junto às incubadoras dos bebês, muitas mães ainda em choque com a aparência física do bebê, muito diferente do que havia sido imaginado, ressentem-se do enxoval não preparado, do quarto do bebê não finalizado, do chá de bebê cancelado.

Não existe tempo de preparação para os acontecimentos que ocorrerão dentro de uma UTI Neoanatal. Em alguns casos, como em uma gestação de risco, ainda que os pais saibam da grande possibilidade de ter seu bebê internado em UTI Neonatal, e tentem se preparar para a experiência, não há como estar totalmente preparado para o que lá se irá viver. É possível antecipar alguma coisa da experiência, mas não tudo.

Os excessos do ambiente (luzes, apitos, monitores, cheiros) incomodam os bebês e os pais. Se estivessem em casa, teriam acesso ao seu bebê a qualquer momento, podendo tocá-lo ou pegá-lo no colo. Na UTI Neonatal não é assim. Muitas vezes, devido ao tamanho diminuto dos bebês, dias ou semanas serão necessários para que os pais possam tê-los em seus braços. E, mesmo que o bebê tenha tamanho suficiente e esteja suficientemente estável, como ele se encontra em uma incubadora, os pais necessitam sempre recorrer a alguém da equipe de saúde para colocar seu bebê em seu colo. Inúmeros pais não se sentem autorizados a tocar em seus bebês na UTI Neonatal. Não são raras as vezes em que, ao 
acompanhar os pais pela primeira vez junto ao leito de seu bebê, ouvimos perguntas como: "mas eu posso mesmo tocá-lo?".

Quando pensamos em um bebê prematuro extremo ${ }^{1}$, é preciso ter em mente que, devido às poucas semanas de gestação, eles gastam muita energia em sua autorregulação. E, em razão disso, são pouco responsivos às interações com os pais. Nesse sentido, nas semanas que se seguem ao nascimento de um bebê prematuro extremo, ele estará mais voltado para si e menos disponível para interações com o ambiente.

Estando mais voltado para si, o bebê é incapaz de parentalizar seus pais. Assim, estes não recebem respostas do bebê indicando que estão no caminho certo no processo de se tornar pai e mãe. Mathelin (1999) questiona: "Como sentir-se mãe desse bebê que não dá sinal, que não mama no seio, que não olha, que não sendo em momento algum tranquilizante, não fabrica mãe?” (p. 67).

O bebê imaginário, que os pais sonharam durante a gestação, muitas vezes é tão diferente do bebê real que a elaboração desta diferença pode superar o tempo de internação do bebê. Ainda que seja por reflexo, costuma ser um momento de muita emoção para os pais, quando os bebês pequeninos seguram um dedo de sua mão. Alguns pais não interpretam o gesto como mero reflexo e se sentem reconhecidos por seus filhos nesses momentos: "É como se muitos pais esperassem uma garantia ou, pelo menos, sinais consistentes por parte do bebê de que podem investir afetivamente nesta relação, sem ameaças de perda" (Zornig, Morsch \& Braga, 2004, p. 141).

Algumas mães questionam se a culpa pelo parto prematuro foi sua, se poderiam ter feito alguma coisa para evitá-lo. Não tendo conseguido levar a gestação adiante, será necessária uma equipe especializada para que o bebê sobreviva. Diante desse desfecho, muitas vezes há dificuldade da mãe em se perceber como uma mãe suficientemente boa para seu bebê. E, assim, o

\footnotetext{
${ }^{1}$ De acordo com a Organização Mundial de Saúde, a cada ano nascem aproximadamente 15 milhões de bebês prematuros no mundo. No Brasil a taxa de prematuridade está estimada em $11,5 \%$ do total de nascimentos, ou seja 345.000 crianças de um total de 3.000 .000 de nascimentos. Uma gestação a termo ocorre por volta de 40 semanas de gestação. O bebê é considerado prematuro (ou pré-termo) quando nasce antes de completer 37 semanas. A prematuridade pode ser classificada como: prematuridade tardia - entre 34 semanas e 0 dias e 36 semanas e 6 dias de gestação; prematuridade moderada - entre 32 semanas e 0 dias e 33 semanas e 6 dias de gestação; muito prematuro - entre 28 semanas e 0 dias a 31 semanas e 6 dias de gestação; prematuro extremo - menor do que 28 semanas e 0 dias de gestação. Sites: www.sbp.com.br acesso em 13 de janeiro de 2020; e www.who.int acesso em 13 de janeiro de 2020.
} 
nascimento prematuro dificultaria a entrada da mãe no estado de preocupação materna primária (Winnicott, 1956/2000b), um estado de grande sensibilidade afetiva, através do qual a mãe pode se identificar e atender às necessidades de seu filho.

Na UTI Neonatal, muitas mães entram no estado de "preocupação médicoprimária" (Agman, Druon \& Frichet, 1999), descrito inicialmente como algo negativo, pois a mãe ocuparia uma função mais médica do que maternal. As mães no estado de preocupação médico-primária apropriam-se do vocabulário médico, sabem ler o prontuário, as fichas da enfermagem, passam a entender de medicações e de respiradores.

Acreditamos, no entanto, ser possível identificar um caráter positivo para a preocupação médico-primária (Morsch \& Braga, 2007), pois a mãe, ciente do estado de saúde de seu bebê e compreendendo as questões médicas, consegue se envolver com as questões de seu filho. Esta apropriação materna das questões médicas que perpassam o cuidado com o bebê, permite à mãe, inclusive, participar das decisões sobre as condutas terapêuticas.

Algumas vezes, as equipes médica e de enfermagem sentem-se desconfortáveis quando as mães se apropriam, em demasia (na opinião da equipe), das questões médicas relacionadas ao bebê. É possível notar, inclusive, a apropriação materna de termos técnicos para se referir ao seu filho.

No serviço em que atuamos, quando os pais dos bebês internados são considerados "difíceis" pela equipe de saúde, muitas vezes são implementados "rodízios" dos profissionais para cuidar de um determinado bebê. Para chegar nessa classificação de "pais difíceis" normalmente há uma combinação de fatores: são bebês graves (prematuros extremos ou com alguma malformação) internados prolongadamente na unidade. Estes pais e mães são muito questionadores, procurando compreender (em excesso, na visão da equipe) as condições dos filhos e opinar sobre as decisões de tratamento. Assim, por exemplo, a cada plantão, a equipe de técnicos de enfermagem se organiza de forma que a técnica que cuidou do bebê no plantão passado não esteja com ele no plantão seguinte. Acreditamos que esse rodízio aponta para a enorme dificuldade que é para todos, inclusive a equipe, de lidar com bebês assim tão frágeis.

Nessas situações, especialmente em internações prolongadas, em que os conflitos tornam-se aparentes, há a deterioração da relação família-equipe de 
saúde. Ocorre que, em muitos casos, em um momento de fragilidade da vida do bebê, será a instauração do estado de preocupação médico-primária que possibilitará a transição gradativa da mãe para o estado de preocupação materna primária posteriormente. $\mathrm{O}$ que não seria saudável, nem para a mãe nem para o bebê, é a cristalização materna no estado de preocupação médico-primária, situação que não nos parece incomum quando se trata de um início de vida muito frágil na UTI Neonatal. O acompanhamento psicológico das mães de bebês que precisaram passar pela UTI Neonatal é importante, podendo, em alguns casos, ser feito um convite para que a mãe olhe mais para o seu bebê e menos para os monitores que o cercam.

Ocupar-se de um bebê não é nunca uma tarefa fácil, mesmo quando este nasce a termo e podemos dizer que está "tudo bem", que tudo saiu "conforme o esperado", sem que o bebê tenha precisado passar pela UTI Neonatal. Cuidar de um bebê sempre mobiliza os adultos em suas partes mais frágeis e arcaicas especialmente os pais, mas também os profissionais da primeira infância, inclusive, em neonatologia.

Mathelin (1999) compara a equipe de saúde de UTI Neonatal à tripulação de um navio, sendo importante ter em mente que a boa marcha do navio depende de todos. Não podemos negligenciar que: "são muitas as tempestades a serem atravessadas em um serviço de reanimação neonatal" (p. 81). As tempestades estão relacionadas às intercorrências, que são muitas e frequentes, com os bebês do serviço. São tempestades que nem sempre levam o bebê à óbito, mas que o fantasma da morte muitas vezes está presente.

Além do ritmo estressante de trabalho, da rotina exaustiva, da grande carga emocional que acompanham todos os eventos de uma UTI Neonatal, cada membro da equipe de saúde traz consigo sua história pessoal e a história do bebê que um dia ele foi. É este ser humano, com sua bagagem própria, que estará diante de um bebê frágil, muitas vezes entre a vida e a morte, e de seus pais, no processo de se tornarem pais desse bebê, que veio ao mundo muitas vezes tão diferente do que havia sido sonhado.

De acordo com Séguret (2013), o trabalho em serviço de reanimação pediátrica possui todos os ingredientes de um drama clássico. Um drama dividido em atos após os quais nenhum de seus atores será mais o mesmo. No centro da história está uma criança cercada pelos demais protagonistas. Há um inimigo 
comum a ser combatido: a morte. O ritmo de trabalho e a regularidade das mortes de crianças ameaçam as defesas e comprometem o investimento de cada um. Os cuidadores, neste tipo de serviço, estão submetidos a intensa carga emocional.

Com o intuito de demonstrar a intensa carga emocional a que está submetida a equipe de saúde, Séguret (2013) traz como exemplo a fala de uma enfermeira logo após a decisão de interromper a reanimação de uma criança. Ao ser questionada pela psicóloga a respeito de qual seria a taxa de mortalidade do serviço, ela afirma que a taxa de mortalidade é de $80 \%$, quando em verdade a taxa é de 13\%. Séguret (2013) compreendeu a inversão de números como demonstração do esgotamento emocional da enfermeira logo após a decisão de parar de reanimar uma criança.

No serviço de reanimação pediátrica em que trabalha a autora (Séguret, 2013; 2017), há uma psicóloga que se dedica ao suporte da equipe de saúde, enquanto a outra psicóloga desenvolve um trabalho de apoio às famílias. Séguret (2013; 2017) considera impossível que apenas uma psicóloga dedique-se, ao mesmo tempo e no mesmo serviço de UTI Neonatal, a cuidar da equipe de saúde e das famílias dos bebês internados. Defendendo taxativamente que, uma vez feita a separação das funções da psicóloga dedicada à equipe de saúde e da psicóloga dedicada às famílias, a psicóloga dedicada à equipe não deverá, em hipótese alguma, prestar auxílio às famílias dos bebês acolhidos naquele serviço. A autora justifica seu posicionamento afirmando que, atendendo ao mesmo tempo equipe, os bebês e suas famílias, o psicólogo poderia ter dificuldades no trabalho de acolher o sofrimento da equipe.

Concordamos com Séguret (2013) que o trabalho de suporte à equipe de saúde é um trabalho de interstício, de corredor, de encontros e trocas informais. Em nosso serviço, não havendo psicóloga na UTI Neonatal que se dedique exclusivamente à equipe de saúde, esse trabalho de suporte à equipe é feito pela única psicóloga do serviço, no corredor, em pequenos intervalos. Os movimentos psíquicos que surgem nos cuidadores são de identificação com a criança ou com um parente, mecanismos de negação de sua própria fragilidade.

No serviço em que atua Séguret, acontece semanalmente, há mais de 15 anos, a "hora de pausa". Trata-se de um grupo de fala composto pela equipe de saúde, em que se permite escutar e dar sentido às emoções negativas que surgem em decorrência, por exemplo, do anúncio de agravamento da saúde ou do risco de 
morte de um paciente. A tomada de consciência de seus próprios sentimentos por parte da equipe é fundamental para que esta se adapte às situações e para que atue de acordo com as necessidades dos pais e dos bebês.

Os psicólogos atuantes em serviços de neonatologia podem proporcionar à equipe de saúde que se fale sobre as dificuldades encontradas, assim como se compreenda o bebê e sua família sob outra ótica, além de poder levantar questões relativas à transferência da equipe e às reações de cada membro diante dos casos que se apresentam (Mathelin, 1999).

No serviço de neonatalogia descrito por Mathelin (1999), são feitas reuniões de síntese semanais, sendo convidados todos os membros da equipe, desde o chefe do serviço aos técnicos de enfermagem. Nas reuniões de síntese é recomendado que se fale dos bebês utilizando-se termos não-técnicos. Ressalta a autora que, muitas vezes, os termos técnicos são usados defensivamente pela equipe. Quando a equipe pode se referir aos bebês a partir de termos não-técnicos, os membros acabam falando de si mesmos, de suas reações ao lidar com determinado bebê, de seus filhos e de sua infância. Durante as reuniões de síntese, nenhuma interpretação é feita, pois, caso contrário, tratar-se-ia de uma interpretação selvagem.

As reuniões de síntese representam um espaço para se compreender qual bebê provoca agressividade, simpatia ou antipatia no serviço, permitindo que a equipe compreenda os mecanismos de projeções e conflitos no trabalho. Tema frequente na reunião, a separação tanto se refere à morte dos bebês, pois as crianças que chegam ao serviço estão muitas vezes em risco de morte, quanto ao momento da alta. O luto também está presente para a equipe quando um bebê recebe alta:

[...] a equipe deve fazer o luto de ser uma boa mãe todo-poderosa que daria a vida aos filhos. É a este preço que um lugar pode ser dado às mães no serviço. Este fantasma não é tão fácil de ser superado e cada reunião nos levará, de um modo ou de outro, a nos interrogarmos novamente a este respeito. (Mathelin, 1999, p. 97)

É interessante pensar que, talvez em nenhuma outra unidade de tratamento intensivo, a equipe de saúde trabalhe sob os olhares de pessoas de fora do serviço, como é o caso da UTI Neonatal, em que os pais estão presentes, se não o tempo todo, durante longos períodos. Mathelin (1999) questiona o que seria mais difícil para um médico do que trabalhar sob o olhar de um pai e de uma mãe. 
As reuniões de síntese permitem que questões da equipe em relação aos pais dos bebês também sejam colocadas. Os membros da equipe podem ser alvo das projeções parentais, sendo algumas vezes vistos como super-homens, outras vezes como monstros. É importante que a equipe se dê conta de que, na maioria das vezes, as projeções parentais são mecanismos de defesa dos quais os pais lançam mão para se proteger. Concedendo-se este espaço de fala para a equipe, os mecanismos de defesa dos pais podem ser melhor compreendidos pela equipe, assim como é possível que compreendam a sua própria transferência em relação ao pai ou à mãe de determinado bebê.

Séguret (2013) indica que um lugar aparentemente frio, altamente tecnológico, barulhento, como o serviço de reanimação pediátrica, é de fato um lugar de projeções, de fantasmas arcaicos, de desejos, de palavras, de calor e, algumas vezes, de hubris, de desmesura. É também um local de humanização do bebê cuidado e de reconhecimento em si da criança hospitalizada. Permite o encontro com as origens do sujeito, com as primeiras experiências.

Um espaço destinado à expressão e ao reconhecimento dos afetos, das projeções e das angústias dos cuidadores é a melhor garantia para o reconhecimento da humanidade das crianças. Mathelin (1999) parece concordar com Séguret quando diz que o papel do analista em UTI Neonatal é o de abrir espaço para que certo tipo de fala e de escuta seja possível: "O lugar do analista, cada vez diferente, deve ser recriado dia após dia. Deverá permanecer flutuante e maleável" (Mathelin, 1999, p. 89).

Para além de cuidar do bebê, é a equipe que receberá os pais nesse ambiente inóspito, totalmente desconhecido pelo bebê e por sua família. A relação que se estabelece entre a equipe e os pais poderá ou não facilitar a criação de vínculo entre os pais e seu bebê que veio ao mundo tão diferente do imaginado.

A equipe de saúde, altamente especializada e cercada de tecnologia, precisa realizar atos precisos e urgentes para a manutenção da vida dos bebês. Rabello (2004) ressalta que, em uma UTI Neonatal, todos se dedicam a salvar o bebê em risco, inclusive o próprio bebê. $\mathrm{O}$ mistério relacionado à UTI Neonatal está no fato de ser um ambiente cercado pelo medo da morte e pela esperança de vida. A ameaça de morte é constante nesse ambiente, contribuindo para a acentuação do desamparo de todos os atores envolvidos, inclusive da equipe de saúde. A vulnerabilidade dos bebês expõe a vulnerabilidade e a finitude dos 
adultos que dele se encarregam: "O ambiente da UTI nos reenvia a todo momento a essa dura realidade de que persistimos em negar: não somos imortais. A vida pode nos escapar a qualquer instante, sem que saibamos quando" (Rabello, 2004, p. 179).

A tecnologia de ponta de uma UTI Neonatal não é garantia absoluta para a manutenção da vida de um bebê: "Ser intensivista é querer vencer a morte, ainda que às vezes não se possa evitá-la. Dura realidade que confronta as equipes no limite atual do desenvolvimento da ciência e que as coloca às vezes numa profunda confusão face às famílias que sofrem" (Druon, 1999, p. 44).

O ambiente da UTI Neonatal escancara a dura realidade de que os vínculos podem ser rompidos abruptamente. E, sendo a UTI Neonatal localizada dentro de uma maternidade, local de celebração da vida, somos muitas vezes obrigados a encarar a morte prematura de um bebê. As experiências comportamentais, emocionais e fantasmáticas dos bebês e da equipe estão interrelacionadas e as emoções de uns entram obrigatoriamente em ressonância com as dos outros. Não há como a equipe de saúde escapar das agonias primitivas (Winnicott, 1963b; Davis 1982) quando se cuida de um bebê prematuro extremo: "Pois o feto, objeto de cuidado, é igualmente um objeto nostálgico que vem reavivar em cada um sua história pré-natal" (De Wailly, 2014, p. 49, tradução nossa).

O ambiente da UTI Neonatal é potencialmente traumático para o bebê, para seus pais e, acreditamos, também para a equipe de saúde. No serviço em que atuamos, a maioria dos casos recebidos na nossa unidade é de bebês prematuros extremos. Desta forma, a equipe está sempre, diariamente, sendo confrontada com a possibilidade de morte de um desses bebês. Apesar disso, pouco se fala sobre a morte e sobre a possibilidade de alguns bebês serem encaminhados para a UTI Neonatal para que sejam assistidos em seus últimos momentos e para que seus pais possam acompanhá-los no processo de morrer.

\footnotetext{
Os incessantes avanços científicos recuam a cada dia os limites da morte. Crianças que não eram viáveis há alguns anos podem hoje ser salvas graças aos cuidados extremamente sofisticados da reanimação neonatal. [...] A cada dia os limites do possível estão um pouco mais longe. Como não se inquietar com isso? (Mathelin, 1999, p. 83)

Dando continuidade a este tema, pensemos na dificuldade enfrentada pela equipe de saúde em fazer face à morte dos bebês cuidados no serviço. A morte de um bebê aponta para uma inversão da ordem natural da vida, em que nascemos,
} 
vivemos e morremos. Além disso, a morte de um bebê levanta questões sobre a nossa própria finitude. Se não podemos salvá-los, poderemos nos salvar?

\section{1}

\section{O fantasma da morte em UTI Neonatal}

Desde o início do nosso trabalho na UTI Neonatal, chamou-nos atenção a forma como especialmente as técnicas de enfermagem referem-se aos bebês dos quais estão encarregadas naquele dia. Diariamente, as técnicas dividem os bebês em grupos de quatro, que durante aquele plantão serão "seus filhos". Isso está tão enraizado na cultura do ambiente que, ao entrar na UTI, o pai ou a mãe são informados pela técnica de enfermagem que "hoje o seu filho é meu filho". Algumas mães parecem gostar de escutar essa frase, pois a técnica de enfermagem estaria cuidando de seu bebê como se fosse seu próprio filho. Outras mães parecem ficar bastante incomodadas, pois as técnicas de enfermagem estariam roubando seu lugar de mãe diante de seu bebê. Questionamo-nos se essa forma de se referir aos bebês não dificultaria a manutenção de uma boa distância entre equipe de saúde, bebês e famílias; inclusive no que se refere à discussão da equipe em relação à possibilidade de que alguns bebês irão morrer, independentemente de todo o esforço em mantê-los vivos.

A manutenção da boa distância é fundamental para que a equipe de saúde não perca sua capacidade de pensamento, de acolhimento e de auxílio aos pais e aos bebês nessa difícil jornada na UTI Neonatal. O enquadramento da situação auxiliará na manutenção da boa distância, permitindo que a equipe sinta com os pais, mas sem se confundir com eles. A dor da equipe de saúde quando morre um bebê não é a mesma dor que enfrentam os pais dos bebês internados, e isso é interessante para pensar em uma situação em que uma técnica de enfermagem se sentiu traída por um bebê que morreu em um dia em que ela não estava de plantão. Ela queixava-se genuinamente por não ter tido tempo de se despedir, como se ele fosse, de fato, seu filho, ao mesmo tempo em que fazia um paralelo com o falecimento de seu próprio pai no início daquele mês.

Bebês abaixo de $500 \mathrm{~g}$ e com menos de 22 semanas são considerados abortamento pela legislação brasileira. José, um bebê de 22 semanas e pouco menos que 500g, nasceu vivo, respirando e o neonatologista da sala de parto 
optou por encaminhá-lo para a UTI Neonatal. Era o segundo filho do casal que nascia com 22 semanas, mas dessa vez haveria a possibilidade de os pais verem o bebê com vida, apresentá-lo à família se assim desejassem, para, então, se despedirem. José sobreviveu 48h, tempo demais para ficar na sala de parto aguardando sua morte. Alguns membros da equipe de saúde da UTI Neonatal expressaram entre si o desconforto de ter esse bebê ali, questionando a decisão médica, pois, agora, seriam eles os responsáveis por acompanhar esse bebê até que ele viesse a falecer, além de terem que testemunhar o sofrimento dos pais.

Concordamos com Mathelin (1999) quando a autora diz que cabe aos responsáveis pelo serviço explicar a tomada de tal decisão. Compreendendo o motivo da decisão, a confiança entre os membros é mantida e a equipe de saúde sente-se em segurança. Questionamo-nos se não foi justamente essa explicação que faltou no caso do bebê José. Na ausência de uma explicação, a equipe sentiuse insegura para estar diante de um bebê que faleceria em poucos dias. Além disso, a autora destaca um ponto importante levantado a partir das reuniões de síntese realizadas em seu serviço: não escamotear a morte. "Uma vida de dois dias é, apesar de tudo, uma vida, tendo um início e um fim, uma história de ser humano que se inscreve em toda uma problemática familiar" (Mathelin, 1999, p. 113). Assim, quando um bebê morre no serviço, é nas reuniões de síntese que será possível falar de afetos e emoções suscitados nos membros da equipe. O papel do analista no serviço de tratamento intensivo é justamente permitir que se fale de morte, evitando-se o "silêncio atroz".

Pedro, um bebê de 24 semanas, nasceu em sofrimento fetal muito grande devido a um descolamento de placenta. Diante da enorme perda de sangue, sua mãe precisou ficar internada na UTI Materna durante quase um mês. Ao longo da internação de Pedro, constatou-se hemorragia cerebral grau 4, o grau mais elevado de hemorragia, que poderia deixá-lo com graves sequelas e seu desenvolvimento poderia ser comprometido. Mesmo com inúmeros exames comprovando a gravidade da situação, ainda que Pedro tenha sido reanimado inúmeras vezes durante sua internação, a equipe tinha dificuldade em falar com os pais sobre a possibilidade de Pedro morrer. Era como se para Pedro lhe restasse a única opção: sobreviver, reassegurando, assim, à equipe o seu potencial de salvar vidas. E, para os pais, era dito que precisavam ter esperança. 
Paula, uma bebê nascida a termo, teve uma asfixia gravíssima durante o período de expulsão no parto, precisando ser reanimada ainda na sala de parto. Encaminhada imediatamente para a UTI Neonatal, Paula seguiu o protocolo de resfriamento da unidade, um estudo realizado em diversos hospitais que consiste em resfriar o corpo do bebê para que a área de dano cerebral seja limitada/reduzida. Apesar do esforço da equipe, os dias que se seguiram mostraram que quase não havia atividade neuronal no cérebro de Paula e, caso sobrevivesse, haveria grandes chances de ter uma vida vegetativa: não iria sugar, deglutir, abrir os olhos, nem interagir com seus pais e irmãos. Ao longo dos atendimentos da psicóloga com Ana, mãe de Paula, frequentemente ela expressava sua angústia ao entrar na UTI Neonatal, onde ela sentia que velava o corpo da filha.

Um mês após o nascimento de Paula, Ana começou a expressar para alguns membros da equipe médica sua vontade de que sua filha morresse, pois não era essa a vida que ela havia sonhado para sua filha nem para si. A equipe, no entanto, tinha grande dificuldade de ouvir Ana expressar seu desejo de morte e frequentemente tentava confortá-la com palavras positivas e com saberes religiosos. Era muito difícil para a equipe acolher os sentimentos de Ana. Esse foi um caso muito emblemático e, caso houvesse espaço de reflexão para a equipe de saúde, teria sido uma grande oportunidade para se começar a discutir sobre cuidados paliativos na UTI Neonatal. Impossibilitados de acompanhar a morte de Paula, sem interferir com manobras de reanimação, Paula foi, por desejo da família e com o consentimento da equipe, transferida para outra UTI, onde, dias depois, teve direito de morrer.

Procuramos ilustrar a partir dos casos apresentados acima o grande desamparo da equipe de saúde da UTI Neonatal, bem como a enorme dificuldade em lidar com a temática relacionada à morte. Muitas vezes a morte torna-se um fantasma que assombra a equipe da UTI Neonatal. Não são raras as vezes em que a equipe solicita aos pais de um bebê que está precisando ser reanimado que espere ao lado de fora da UTI Neonatal. Aos pais é dito que será melhor para eles não estarem ali. No entanto, questionamo-nos se a real dificuldade não estaria em trabalhar sob o olhar do pai e da mãe do bebê, tendo que responder às suas perguntas na hora e acompanhar a sua dor de ver seu filho passar por uma reanimação. 
Por mais dramática que possa parecer a cena de reanimação de um bebê, nós acreditamos que, se um bebê deve ser acompanhado por seus pais no nascimento, ele também deve ser igualmente acompanhado por seus outros fundamentais na hora da morte. O bebê que está morrendo necessita do mesmo continente que teve para nascer. Pensemos na escultura "Pietà" de Michelangelo como exemplo do acompanhamento da morte de Jesus pela Virgem Maria: todas as mães deveriam ter o direito de segurar seus filhos no colo no momento da despedida. Assim como os bebês deveriam ter o direito de serem segurados nos braços por seus outros fundamentais e de serem contidos física e psiquicamente na hora da morte.

Não são raros os relatos de médicos e enfermeiros que apontam para a falta de matérias na faculdade de Medicina e de Enfermagem para lidar com o tema da morte. Acreditamos que a equipe de saúde, diante do desamparo que se encontra ao lidar com a morte, necessita recorrer a mecanismos de defesa como a clivagem para não enfrentá-la. Dessa forma, fala-se apenas em vida, em sobreviver e em salvar os bebês, ainda que diariamente sejam confrontados com a morte. Não se pensa coletivamente sobre a morte, nem se discute com os pais sobre qual seria a qualidade de vida desses bebês, caso venham a ter alta da UTI Neonatal.

A falta de um espaço para a equipe de saúde da UTI Neonatal refletir sobre a morte traz consequências para os bebês, para suas famílias e para a própria equipe. Em relação aos bebês, fica impossibilitada a discussão sobre a qualidade de vida daqueles que eventualmente podem sobreviver com sequelas gravíssimas, assim como a implementação de cuidados paliativos para os bebês atendidos pelo serviço, mas este tema, apesar de extremamente relevante e fundamental, não é o foco do presente estudo.

Acreditamos que a falta de um espaço de fala acentua o desamparo da equipe, impedindo o acolhimento dos cuidadores e a elaboração dos seus sentimentos diante da morte ou da iminência de morte de algum paciente. Estudos, como os de Fogaça, Carvalho, Cítero e Nogueira-Martins (2008), Monteiro (2012) e Moraes e Granato (2014), apontam para um risco maior de adoecimento dos membros da equipe de saúde de UTI Neonatal, com consequente aumento do número de faltas, afastamento por doenças, além de um risco elevado de burnout. 
De acordo com Mathelin (1999), a angústia atinge todos os membros da equipe de saúde, promovendo um aumento de riscos depressivos e de agressividade. A equipe de saúde que já atua com um número bem enxuto de profissionais - pensemos, por exemplo, na proporção de uma técnica de enfermagem para cada quatro bebês -, com a falta de algum membro da equipe e na impossibilidade de convocar alguém para substituir aquele que precisou se ausentar, será forçada a redividir o número de pacientes no dia. Ou seja, um trabalho que já é demandante física e emocionalmente, se torna ainda mais extenuante.

Fazer face e digerir emocionalmente os eventos vividos pela equipe de saúde requer tempo e reflexão sobre o assunto, mas em uma UTI Neonatal não há tempo, há urgência. Gostaríamos de ilustrar a tensão do ambiente com a seguinte cena. Logo na entrada da UTI Neonatal, um bebê tem uma parada cardíaca e precisa ser reanimado. Parte da equipe está ali com ele e, por trás das máscaras, é possível ver os olhos atentos e tensos da equipe, suas luvas com sangue. Nesse mesmo instante, outra parte da equipe está recebendo um bebê que acaba de nascer. Apesar dos esforços, o bebê, que estava sendo reanimado, faleceu. Mas, para a equipe, não haverá minutos de intervalo entre começar a preparar o corpo do bebê falecido para levá-lo ao necrotério e o início dos cuidados com o bebê recém-chegado na unidade. Tudo acontece ao mesmo tempo. Rabello (2004), ao comentar um caso mãe-bebê que acompanhou em uma UTI Neonatal, afirma que, neste ambiente, as defesas psíquicas estão em risco de desmoronamento. Nós concordamos com a autora, mas acreditamos ser importante ressaltar que o risco de desmoronamento das defesas atinge igualmente a equipe de saúde.

Mathelin (1999) afirma que o papel do analista em UTI Neonatal é dinâmico, pois ele é, ao mesmo tempo, parte da equipe, mas, em determinados momentos, necessita distanciar-se para compreender melhor a questão que surge dentro da equipe. Em outros momentos, o analista estará ao lado da equipe para acompanhar um bebê que morre. $\mathrm{O}$ analista deve:

[...] ajudar os pais a serem seus pais [pais do bebê] apesar de tudo, não deixar nem a família, nem a equipe confundir a criança com o aparelho. Fazer com que todos preservem a capacidade de pensar. Falar da morte, para que a morte psíquica não invada tudo, para que ela não predomine sobre a morte do corpo. (Mathelin, 1999, p. 90) 


\section{2}

\section{Trauma e denegação da morte}

O contexto de UTI Neonatal é de vulnerabilidade, gravidade e risco, a ameaça de morte é uma constante. Neste ambiente, são acentuadas as condições de desamparo humano - do bebê, dos pais e da equipe de saúde. Os vínculos são rompidos abruptamente. E tudo é muito diferente do que poderia ter sido imaginado.

A equipe se identifica com o desamparo do bebê, precisando lançar mão de defesas para lidar com o seu próprio desamparo. Desta forma, podemos dizer que algumas defesas são necessárias, pois são elas que permitirão o desempenho do trabalho. Pensemos no exemplo de um médico que precisa puncionar a veia de um bebezinho de $500 \mathrm{~g}$. Através do campo cirúrgico ${ }^{2}$, só é possível ver o diminuto braço do bebê e todo o bebê fica escondido atrás do campo cirúrgico. Ora, é necessário que, por alguns minutos, o médico concentre-se em apenas obter acesso à veia do bebê, esquecendo-se momentaneamente que se trata de um bebê, que sente dor. É um ato que requer precisão. Qualquer vacilo do médico poderá causar ainda mais desconforto para o bebê.

Os cuidadores possuem a consciência profunda e muitas vezes angustiante de que a vida da criança depende de seus gestos, de sua experiência, e eles podem experimentar sentimentos agressivos e arcaicos de onipotência, de devoração, de perseguição e de morte. Os cuidadores de reanimação pediátrica, tal como acontece com as mães, estariam submetidos ao traumatismo que representa a ultradependência de uma criança hospitalizada (Séguret, 2013).

Haveria, então, uma identificação dos cuidadores com o que vive a criança hospitalizada em serviço de reanimação pediátrica. Uma vivência de desamparo, tal como as agonias primitivas descritas por Winnicott (1963b; Davis, 1982), sendo o sujeito exposto a sentimentos de aflição e solidão extrema, combinados com a experiência de desintegração.

Para cuidar de bebês frágeis e em risco de morte, é necessário que o médico entre em um funcionamento onipotente, em que certa denegação da morte é importante para que se possa atuar e salvar os bebês. No entanto, a radicalização

\footnotetext{
${ }^{2}$ Campo cirúrgico (ou campo operatório) é um tecido esterelizado que cobre todo o corpo do bebê, deixando aparente apenas o membro ou área do corpo que sofrerá intervenção cirúrgica.
} 
da onipotência e da denegação da morte pode ter efeitos disruptivos para as famílias e para a equipe de saúde da UTI Neonatal.

Acreditamos que a denegação da possibilidade de morte de algum bebê é o que torna o serviço na UTI Neonatal ainda mais difícil e potencialmente traumático para a equipe de saúde. Há uma clivagem entre a vida e a morte. Só há espaço para pensar e falar em vida, dificultando enormemente o posicionamento da equipe diante das mortes inevitáveis no serviço. A morte, evento natural da vida, passa a ser um fantasma que assombra a equipe. Psiquicamente, é necessário que se dê sentido ao que se vive, e só é possível dar sentido às experiências se elas forem faladas, compartilhadas, pensadas e digeridas.

Ao retomarmos a teoria freudiana, notamos que a partir de 1920 o autor revisa sua concepção do trauma para nela incluir, não só os aspectos pulsionais mas também o impacto do evento externo no psiquismo do sujeito. Nesta perspectiva, como indica Rudge (2009), o trauma decorreria da articulação entre o evento externo e a organização psíquica e história individual, da singularidade de cada sujeito. (Freud, 1920/2010; Rudge, 2009).

Lembramos que Freud, a partir da segunda tópica, interessou-se pela neurose traumática, abdicando do seu entendimento de que todo sonho, caminho seguro para a investigação de processos psíquicos profundos, obedece ao princípio do prazer:

[...] sentimo-nos encorajados a supor que na vida psíquica há realmente uma compulsão à repetição, que sobrepuja o princípio do prazer. Também nos inclinaremos a ligar a essa repetição os sonhos das vítimas de neurose traumática e o impulso que leva as pessoas a brincar. (Freud, 1920/2010, p. 183)

Diante das barbáries enfrentadas durante as guerras, em especial a Primeira Guerra Mundial, o trauma volta ao interesse dos psicanalistas. Soldados retornam do front com neuroses provocadas pela guerra, relatando acidentes traumáticos e sonhos através dos quais eles são reeditados.

A neurose traumática aponta para uma situação extrema que rompe as barreiras de proteção do sujeito, e que não pode ser assimilada pelo sujeito e nem esquecida, vindo acompanhada de sonhos repetitivos que não obedecem ao princípio de prazer:

[...] sentimo-nos encorajados a supor que na vida psíquica há realmente uma compulsão à repetição, que sobrepuja o princípio do prazer. Também nos inclinaremos a ligar a essa 
compulsão os sonhos das vítimas de neurose traumática e o impulso que leva as pessoas a brincar. (Freud,1920/2010, p. 183)

Os sonhos traumáticos "tendem a reconduzir o sonhador exatamente à terrível situação que lhe causou intensa angústia" (Rudge, 2009, p. 55). No entanto, de acordo com Rudge (2009), apesar de hoje haver muitas articulações sobre eventos traumáticos e os sonhos, o próprio Freud teria levado tempo para descobrir a relação do sonho com as situações traumáticas para o sujeito.

Nesse sentido, o sonho traumático apontaria para a necessidade de repetir a situação traumática para que possa ser elaborada. São situações angustiantes para o sujeito que retornam nos sonhos traumáticos em um tentativa de ligar psiquicamente o trauma: "Aqui seria, então, o lugar de admitir pela primeira vez uma exceção à tese de que o sonho é uma realização de um desejo" (Freud, 1920/2010, p. 196).

Ao pensar na neurose traumática de guerra, não podemos ignorar a importância da história singular de cada indivíduo, pois não serão todos os soldados que apresentarão os sintomas compatíveis com neurose de guerra.

O trauma é, pois, o impacto de um acontecimento sobre um psiquismo singular, e o solo constituído pela história passada do sujeito na determinação do significado que esse acontecimento assume para ele não pode ser desconsiderado, seu mundo de fantasias deve ser levado em conta. (Rudge, 2009, p. 43)

Escolhemos abordar o trauma a partir dos conceitos de Ferenczi e Winnicott, por enfatizarem a importância do ambiente afetivo na constituição do psiquismo infantil e marcarem como o ambiente pode se tornar desestruturante e potencialmente traumático se não consegue oferecer ao infante uma experiência de sustentação e contenção física e psíquica.

Os acontecimentos da UTI Neonatal, pelo seu caráter potencialmente traumático, acenam para a importância da presença do ambiente afetivo para que o sujeito possa manter o sentimento de continuidade de ser. Em tais momentos, temos sempre a necessidade da presença implicada do outro para que possamos nos manter pensando e vivendo criativamente.

A tradição de valorização do meio ambiente para a saúde psíquica do sujeito iniciou-se com Ferenczi, e foi consolidada por Winnicott, ao propor que se pense o trauma a partir da falha na relação entre sujeito e objeto (Souza, 2003). Estes autores ressaltam a importância da função do ambiente no que se refere à 
capacidade de o sujeito lidar com os eventos potencialmente traumáticos. Nesse sentido, a função do ambiente é fundamental para se pensar no caráter traumático de determinada situação. Nos primórdios da vida psíquica, o trauma impediria a constituição subjetiva.

O evento traumático é uma situação potencialmente disruptiva e o seu acontecimento leva o sujeito a acionar defesas devido ao desamparo e ao grande sofrimento psíquico causado. Entendemos que as ameaças de morte de bebês em UTI Neonatal podem ser potencialmente traumáticas para os profissionais de saúde, causando grande sofrimento psíquico, levando ao adoecimento e, algumas vezes, ao afastamento dos membros da equipe do ambiente de trabalho.

O conceito de trauma sempre esteve presente na teoria ferencziana, mas foi no final de sua vida que ele desenvolveu a teoria de trauma desestruturante ou patogênico. Para Ferenczi (1933/2011), o trauma tem fundamento na confusão de línguas: a linguagem da ternura falada pela criança e a linguagem da paixão falada pelo adulto. O trauma acontece em função de um abuso ou de um excesso, através do qual a linguagem da paixão se sobrepõe à linguagem da ternura infantil. Além de sexual, o abuso pode ser um castigo físico excessivo e também a hipocrisia do adulto sobre a criança.

$\mathrm{O}$ adulto confunde as brincadeiras infantis com os desejos de uma pessoa sexualmente madura, impondo sua passionalidade. A criança sente-se perdida no tocante à segurança e à confiança que depositava no adulto. A violência e a insensibilidade do adulto, que deveria cuidar da criança, se impõem e as necessidades da criança não são observadas. A partir da ocorrência de um ato violento, a criança não consegue construir um sentido para o que ela viveu. $O$ desmentido acontece quando a resposta do adulto é o silêncio, a negação ou o descrédito das vivências da criança em relação ao abuso. A criança fica impossibilitada de dar sentido e de metabolizar o acontecido. Assim, o que é verdadeiramente traumático, não é o ato violento, mas o desmentido do adulto. A verdade da criança não é considerada pelo adulto e, desta forma, não é possível dar sentido ao ocorrido, abrindo-se a ferida traumática.

A comoção psíquica, que diz respeito à aniquilação do sentimento de si é a resposta imediata ao traumático, de modo que o sujeito se torna incapaz de resistir, de agir, de pensar. A dor insuportável perpetrada pelo abuso não pode ser 
ultrapassada e, em consequência, a criança distancia-se de si. Impossibilitada de se defender, a criança aceita o que lhe é imposto.

A dor em excesso não pode ser representada, tendo como resultado um adormecimento. Essa dor não chega à consciência, não se inscreve no inconsciente e nem será recalcada. O que subsiste do trauma são as marcas corporais, inalcançáveis para a memória. $\mathrm{O}$ medo da criança impede a expressão de ódio e de repulsa, submetendo-se, a partir da identificação e da introjeção do agressor e do sentimento de culpa.

Tomamos a liberdade para pensar a comunicação da equipe de saúde de UTI Neonatal, a partir a confusão de línguas (Ferenczi, 1933/2011), baseada na racionalidade do discurso adulto, com um distanciamento do que está ligado aos afetos e às emoções. A equipe de saúde, para cuidar dos bebês, precisa identificarse com eles. São as partes arcaicas de cada sujeito que comparecem nos momentos de cuidados com o bebê. A identificação dos cuidadores com a posição do bebê pressupõe dependência, fragilidade, vulnerabilidade.

Quando Ferenczi descreve o "bebê sábio" (Ferenczi, 1933/1992; Lejarraga, 2008), ele aponta para a incorporação da capacidade intelectual do adulto diante de uma situação traumática. Nesse sentido, o "bebê sábio" vê-se obrigado a renunciar à linguagem da ternura para cuidar de si e dos outros. Para defender-se do horror do trauma, o eu divide-se em dois fragmentos: o primeiro, culpado e amadurecido; o segundo, encoberto e inutilizado. Assim, a criança abandona a ternura para sobreviver, sacrificando parte de si. A perda de espontaneidade é consequência da comoção traumática:

Não deixa de ser paradoxal que a defesa age destruindo uma parte de si para depois proteger os restos dessa quase morte. Esses destroços esmagados da linguagem da ternura tendem a retornar quando encontram um ambiente acolhedor e benévolo, ou seja um analista que não seja hipócrita, capaz de escutar as vozes infantis e as manifestações corporais dessa dor incomensurável que não pôde ser integrada. (Lejarraga, 2008, p. 123)

Neste ambiente potencialmente traumático, tal qual o "bebê sábio" descrito por Ferenczi, não entraria a equipe de saúde da UTI Neonatal em um discurso racional, afastando-se do que é frágil e vulnerável? A equipe sábia não dá testemunho do seu sofrimento, muito embora ele exista. Ainda que se procure escamotear o sofrimento, ele teima em aparecer: seja através de adoecimento, afastamento do trabalho por motivos de saúde, burnout. 
Acreditamos ser importante dar voz ao "discurso bebê" da equipe de saúde, uma vez que ele aponta para a importância da presença implicada de um outro, que possa sustentá-lo emocionalmente. Ao encontrar um ambiente acolhedor, um outro capaz de escutar as vozes infantis e as manifestações dessa dor incalculável que não pôde ser integrada, é possível fazer sentido do que se vive na UTI Neonatal.

Winnicott, assim como Ferenczi, destaca a importância do objeto primordial no processo de subjetivação do bebê, ressaltando como a presença implicada do outro é fundamental ao longo de nossa existência. $\mathrm{O}$ autor, ao afirmar que "there's no such a thing as a baby", enfatiza que o bebê não sobrevive sozinho e só pode ser pensado em sua relação com seus objetos primários.

O bebê humano, ao nascer, mesmo quando nasce a termo, é prematuro e depende dos cuidados do ambiente, isto é, da mãe ou de quem exerce a função materna. A relação com o outro fundamental no início da vida é de dependência absoluta. A partir do desenvolvimento físico e emocional do bebê, e na medida em que vai sendo possível acontecer o fracasso gradativo do outro (Winnicott,1975; Davis, 1982), o bebê entraria em uma fase de dependência relativa, seguindo rumo à independência.

A separação das fases de desenvolvimento em dependência absoluta, dependência relativa e rumo à independência se dá apenas para fins didáticos Winnicott (1963a, 1975; Davis, 1982), pois não há marcos no desenvolvimento que atestem a entrada na fase seguinte. Além disso, ao longo da vida, diante dos acontecimentos, é possível retornar a fases anteriores. E nós acreditamos que ambientes como a UTI Neonatal ressaltam ainda mais a nossa necessidade da presença implicada do outro.

Nesse sentido, é importante ressaltar que a independência nunca é absoluta, pois o indivíduo sempre depende do ambiente em alguma medida ao longo da vida. Winnicott indica uma tendência inata do sujeito para o amadurecimento, sempre considerando a importância do ambiente facilitador. A partir de uma maternagem suficientemente boa, o bebê desenvolve suas potencialidades e estabelece o sentimento de continuidade de ser (Lejarraga, 2008; Winnicott, 1960). 
O desempenho da função materna envolve: o holding, o handling e a apresentação de objetos. Holding é o termo winnicottiano utilizado para designar o suporte, tanto físico quanto psicológico, dado pela mãe ao bebê. Psicologicamente, o ego da mãe oferece apoio ao ego do bebê, que está em constituição. O ego do bebê irá integrar-se a partir do holding suficientemente bom. O suporte físico oferecido pela mãe envolve toda a rotina de cuidados com o bebê: alimentação, banho, troca de fraldas, prevenção de quedas. É através do holding materno que o bebê pode ter a experiência de ser (Winnicott, 1956; Davis 1982).

No início da vida, é importante que o ambiente se adapte totalmente ao bebê para que, na medida em que o bebê se desenvolve, possa haver uma desadaptação gradativa. $\mathrm{O}$ olhar da mãe desempenha a função de espelho para o bebê, que, ao olhar para a mãe, vê a si mesmo (Davis, 1982). Nesse caso, o bebê se relacionará com o ambiente através do gesto espontâneo, quando o ambiente se adapta às suas necessidades, fortalecendo o sentimento de si mesmo. Por outro lado, havendo falha na adaptação do ambiente às necessidades do bebê, há a perda da espontaneidade e ruptura na continuidade de ser.

O trauma, para Winnicott, está na quebra da continuidade de ser, isto é, quando o bebê precisa reagir à intrusão do ambiente. A ameaça à continuidade de ser provoca "agonia impensável": "uma agonia que não pode ser pensada, nem representada, nem integrada" (Lejarraga, 2008, p. 130).

Reagir ao ambiente no momento em que o bebê está se constituindo psiquicamente traz para o bebê uma ameaça de aniquilamento do ser. Winnicott (1963b) exemplifica, sem pretender esgotar as agonias impensáveis: retorno a um estado não-integrado, cair para sempre, perda do conluio psicossomático, perda do senso do real, perda da capacidade de relacionar-se com objetos. Os termos "agonias impensáveis", "colapso" e "trauma" destacam diferentes aspectos de um mesmo fenômeno descrito por Winnicott:

[...] a expressão "agoniais impensáveis" enfatiza a radical sensação de morte psíquica que nem sequer pode ser pensada porque acontece em uma época pré-verbal e pré-psíquica; o termo "colapso" alude à ruptura do si-mesmo unitário e à interrupção de todos os processos básicos do amadurecimento; e o termo "trauma" refere-se também à ruptura da continuidade de ser, enfatizando, contudo, o desconforto entre o ambiente e o indivíduo. (Lejarraga, 2008, p. 130) 
Para Winnicott o trauma pode ser sutil e silencioso e está mais relacionado a sucessivas falhas do ambiente em sua adaptação às necessidades do bebê. $\mathrm{O}$ bebê reage defensivamente às agonias impensáveis através da cisão. A cisão (splitting ou clivagem) isola o self em falso e verdadeiro. Todos os seres humanos estão incluídos nessa cisão entre verdadeiro e falso self, sendo inclusive um sinal de saúde. A cisão será considerada patológica quando tiver função de encobrir o verdadeiro self. O sujeito submete-se ao ambiente, comprometendo o seu gesto espontâneo e a criatividade (Lejarraga, 2008; Winnicott, 1974/1994).

Em relação à equipe de saúde, a clivagem como defesa para poder cuidar do bebê em situação de desamparo é necessária. Inclusive, para que a equipe possa realizar atos precisos para salvar a vida dos bebês: entubar, puncionar acesso venoso, dentre tantos outros procedimentos invasivos e dolorosos para o bebê. No entanto, a defesa em excesso comprometeria o gesto espontâneo e a criatividade da equipe no desempenho de suas funções.

Winnicott (1964) destaca que, após o nascimento de um bebê, a díade mãe-bebê precisará ser sustentada pelo pai, que por sua vez precisará ser sustentado pela sociedade. A equipe de saúde de UTI Neonatal também precisa ser sustentada pela instituição para que possa desempenhar suas funções. Acreditamos que a falta de um espaço potencial para a equipe falar do desamparo do bebê e de seu próprio desamparo acentua o potencial traumático do ambiente de UTI Neonatal. 


\section{3 Identificação projetiva no ambiente da UTI Neonatal}

Neste ambiente cercado de tecnologia que é a UTI Neonatal, onde a tensão entre a vida e a morte está sempre presente, "É preciso pouca coisa para que os conflitos surjam entre os pais e a equipe de saúde. Há um efeito de lupa do serviço sobre os conflitos internos dos pais, e os profissionais são alvo das projeções intensas dos pais" (Druon, 1999, p. 43).

Cenas como a que iremos descrever não são incomuns no serviço. Durante uma internação prolongada de um bebê prematuro extremo, a chefe de enfermagem é chamada pela mãe. A mãe acusa a equipe de ter roubado um pé do par de meias de seu filho. Não roubaram o par, roubaram apenas um pé. Somos chamadas pela enfermeira chefe, que nos relata o ocorrido. Essa cena com o relato de um roubo nos faz pensar na dificuldade que é para a mãe ter seu bebê internado em um serviço de terapia intensiva. A equipe que garante a sobrevivência do bebê, ao mesmo tempo rouba da mãe seu bebê, impedindo-a de cuidar pessoalmente dele e, consequentemente, de realizar seu papel de mãe. A relação pais e equipe de saúde muitas vezes é marcada por ambivalência e serão muitos os conflitos, velados e explícitos a serem enfrentados.

Sentimentos como angústia, tristeza e raiva estão presentes neste ambiente onde a equipe de saúde acompanhará pais e mães em um período extremamente delicado. Os recursos psíquicos dos pais dos bebês internados, únicos e dependentes da história pessoal de cada sujeito, podem ser destruídos em situações extremas vividas dentro da UTI Neonatal. Soubieux (2013) afirma que a em um primeiro momento, ao ter seu bebê encaminhado para a UTI Neonatal, o psiquismo dos pais fica congelado pelas proteções das quais precisam lançam mão para se defender. É uma tentativa de sobreviver à avalanche de emoções a que estarão sujeitos. O respeito pelas defesas psíquicas dos pais poderá permitir a suavização das defesas em um segundo momento.

A equipe desempenha um papel fundamental em situações de grande sofrimento psicológico ao oferecer aos pais condições favoráveis para a expressão do sofrimento e para a reapropriação da capacidade de pensar. A pluridisciplinaridade da equipe garantirá a continuidade e a contenção necessárias 
neste momento de caos psíquico. Criando-se um envelope ao redor dos pais, estes poderão retomar a sua capacidade de pensar e se alicerçar em seus próprios recursos internos (Soubieux, 2013).

Soubieux (2013) ainda afirma que, nesses ambientes, ressurgem a cólera, o ódio e mecanismos psíquicos muito arcaicos: a clivagem, a identificação projetiva, a negação, as projeções persecutórias. Utilizaremos o conceito de "identificação projetiva" para refletir sobre as vicissitudes e os impasses que surgem entre os profissionais e os pais neste ambiente que já é carregado de tensão pela constante confrontação entre vida e morte.

Em "Notas sobre alguns mecanismos esquizóides" (1946/1991a), um dos principais trabalhos de Melanie Klein, são apresentados minuciosamente os processos psíquicos relativos aos três primeiros meses de vida do bebê. O termo “identificação projetiva" é utilizado pela primeira vez quando da descrição da posição esquizoparanóide. Identificação projetiva é um conceito amplo, relacionado a diferentes processos, nos quais cisão, projeção e introjeção estão presentes e são apontados pela autora como mecanismos de defesa do ego contra a ansiedade (Klein, 1946/1991a).

Klein utilizava os conceitos de projeção e identificação descritos por Freud em "Totem e tabu" (1912-1913/2012), até que em 1946 introduziu o conceito de identificação projetiva (Gibeault, 2000). As relações de objeto estão presentes desde os primórdios da vida do sujeito, assim como os processos de projeção e introjeção, cujos conteúdos dizem respeito a afetos e a objetos. O primeiro objeto seria o seio materno, que, cindido pelo bebê em seio bom (gratificador) e seio mau (frustador), possibilita a separação das emoções em amor e ódio. Através da projeção do ódio e do amor, nasce o objeto externo. O objeto interno é um objeto incorporado pela introjeção desse objeto amado ou odiado. A internalização do objeto bom servirá de base para a construção do ego. Segundo Klein (1946/1991a), já existe um supereu primitivo desde o nascimento, que antecede o supereu edípico. O objeto incorporado assume função de supereu, que será mais ou menos persecutório de acordo com o predomínio do ódio ou do amor. Havendo prevalência do amor sobre o ódio, ocorre a projeção e a introjeção do objeto bom e, consequentemente, a elaboração da posição esquizoparanóide para a posição depressiva. 
A projeção relaciona-se ao movimento de expulsão dos excrementos, característico do estágio sádico-anal. A introjeção está ligada ao movimento de incorporação e, portanto, relacionado ao estágio sádico-oral. A criança expulsa o objeto hostil, analogamente aos seus excrementos. O supereu aterrorizante, introjetado no estágio sádico-oral, é expulso e projetado no mundo exterior. Os mecanismos de projeção e de expulsão estariam relacionados à formação do supereu. O primeiro movimento em direção ao objeto é descrito a partir da deflexão da pulsão de morte. Este processo condiciona as relações objetais do indivíduo e é a base do mecanismo de projeção. A incorporação refere-se à incorporação parcial de um objeto mau e perseguidor, núcleo do supereu. A angústia que surge a partir da introjeção deste objeto provoca mecanismos de expulsão e de projeção (Gibeault, 2000).

A abordagem cronológica dos mecanismos de deflexão, introjeção oral e projeção anal é teórica. São processos interrelacionados e foi isso que permitiu à Klein conferir status metapsicológico à projeção. A projeção é descrita como mecanismo de proteção do eu contra objetos incorporados perseguidores através de um deslocamento para fora do eu da fonte de perigo. E, ao mesmo tempo, a projeção contribui para a descoberta e observação do mundo externo. Os dois mecanismos (projeção e identificação) possuem importância fundamental para a formação do supereu, para a relação entre pessoas e para a adaptação à realidade (Gibeault, 2000).

$\mathrm{Na}$ identificação projetiva, há a identificação com o outro e a projeção de seus próprios sentimentos e pensamentos. Klein (1959/1991b) considera esse movimento de projeção amigável o fundamento da empatia, sendo possível colocar-se na pele do outro. A identificação projetiva de partes boas de si permite compreender o outro empaticamente.

A dimensão progressiva do funcionamento mental era, até então, relacionada à introjeção oral do seio bom. Klein (1946/1991a) concorda com Winnicott sobre a não integração do ego arcaico, sugerindo que nos primeiros meses de vida há tanto uma tendência à integração quanto à desintegração. Com a definição de identificação projetiva boa, a ideia de dimensão progressiva do funcionamento mental é retomada e pode-se falar em integração e desenvolvimento. Produzida excessivamente, a identificação projetiva boa pode se tornar ruim, ocasionando um enfraquecimento do eu, pois as partes boas do eu são 
sentidas como perdidas. $\mathrm{O}$ excesso do movimento de empatia apresenta o risco de o sujeito se perder no objeto. A consequência do desaparecimento do sujeito está na provável incapacidade do sujeito de realizar julgamento objetivo. A identificação projetiva excessiva aponta para um sentido ruim, com os riscos intrínsecos à identificação por projeção das partes boas e da identificação por projeção das partes ruins. De acordo com Gibeault (2000), Klein considera que a simpatia real e a compreensão do outro serão transformadas quando a projeção é de natureza hostil.

O caráter negativo do mecanismo de identificação projetiva foi apresentado por Klein (1946/1991a) para caracterizar o modelo de relação de objeto agressiva, correspondente a uma clivagem excessiva do objeto e do eu em uma parte idealizada e uma parte persecutória. A identificação projetiva descreve o processo através do qual o bebê projeta para a mãe o ódio antes voltado para partes do ego, fazendo com que a mãe seja sentida como perseguidora. $\mathrm{O}$ excesso de projeção, mesmo de conteúdo agressivo, pode enfraquecer o ego, pois a agressividade também está relacionada com “poder, potência, força, conhecimento e muitas outras qualidades desejadas" (Klein, 1946/1991a, p. 27).

O controle exercido sobre o objeto é essencial para o conceito de identificação projetiva, não sendo apenas da expressão de um fantasma. Trata-se de uma pressão real sobre o objeto, com intenção de influenciá-lo e comprovar dois elementos do fantasma: a) as partes projetadas do eu são idênticas às partes do objeto; e b) o controle é exercido pelo sujeito. A pressão externa exercida pelo sujeito no objeto explica que o objeto pense, sinta e se comporte de acordo com o fantasma projetivo (Gibeault, 2000).

De acordo com Gibeault (2000) Bion propõe a ampliação da compreensão da identificação projetiva para um modo de comunicação primitiva a serviço do princípio de realidade, a partir do que foi descrito por Klein em relação à identificação projetiva excessiva como mecanismo de defesa a serviço do princípio do prazer. Utilizando-se da identificação projetiva, o eu procura modificar a realidade ao projetar no objeto conteúdos maus para que o objeto possa digeri-los e disponibilizar objetos bons para a reintrojeção.

A metáfora continente-conteúdo de Bion serviu de base para a elaboração da teoria da identificação projetiva como modo de comunicação primitiva. $\mathrm{O}$ mecanismo de identificação projetiva pressupõe a diferenciação entre sujeito e 
objeto e a projeção de um conteúdo em um continente. A compreensão da identificação projetiva como modo de comunicação através do qual o objetocontinente realizará trabalho de elaboração foi muito bem recebido pelos póskleinianos (Ogden, 2010; Gibeault, 2000).

Bion (1962) baseou a sua teoria do continente-conteúdo sobre o modelo de relação existente entre a mãe e seu bebê, estendendo esse modelo à relação analista-analisando. Nós pretendemos estender, como veremos adiante no subitem deste capítulo, esse modelo para a relação equipe de saúde-pais dos bebês internados na UTI Neonatal.

A hipótese teórica bioniana é que o bebê possui uma preconcepção do seio, porém não possui consciência da necessidade do seio bom. Ao sentir fome, o bebê experimenta uma necessidade não satisfeita, que seria o equivalente ao seio mau. Nesse sentido, os pensamentos primitivos ou protopensamentos são objetos maus, dos quais o bebê deve se livrar. Assim, quando um bebê sente fome, a mãe não irá apenas alimentá-lo, ela servirá de continente para os sentimentos de desprazer do bebê. Um continente (a mãe) onde um conteúdo (seio mau) é evacuado pelo bebê: "a evacuação do seio mau na mãe constitui a expulsão de um elemento beta através do mecanismo de identificação projetiva" (Soubieux, 2013, p. 188, tradução nossa)

Os elementos brutos são improdutivos para o pensamento e são expulsos através da identificação projetiva. A função alfa transforma os elementos beta em elementos alfa, ou seja, trata-se de uma função através da qual as impressões sensoriais e as experiências emocionais são convertidas em elementos mnésicos, que serão armazenados para serem utilizados em sonhos e pensamentos inconscientes. Quando nos referimos à identificação projetiva, a intervenção de outra pessoa é fundamental na transformação dos elementos primitivos (Soubieux, 2013).

O conceito bioniano de rêverie materna, isto é, a capacidade onírica da mãe, refere-se a um estado mental em que a mãe pode receber a identificação projetiva do bebê, seja ela boa ou má. A rêverie materna é descrita como a capacidade da mãe de transformar elementos beta (elementos brutos), característicos da evacuação na identificação projetiva excessiva, em elementos alfa (Bion, 1962). 
No início da vida, o bebê necessita de sua mãe para sonhar, pois sozinho ele não é capaz de processar a experiência emocional vivida. A mãe, emocionalmente disponível para o bebê, realiza o trabalho psicológico de sonhar e devolve para o bebê a experiência emocional de forma palatável para que, aí sim, ele possa sonhá-la:

É através da capacidade de sonhar ou devanear da mãe (rêverie materna) que a experiência emocional em estado bruto do bebê é metabolizada e disponibilizada a ele de uma maneira que este seja capaz de processar e desenvolver a capacidade de sonhar e de pensar a própria experiência. (Zornig, 2010, p. 19)

O conceito bioniano de continente está relacionado ao processamento da experiência emocional vivida. Refere-se à forma como pensamos, “ou seja, como processamos a experiência vivida e o que ocorre psiquicamente quando somos incapazes de fazer um trabalho psicológico com aquela experiência” (Ogden, 2010, p. 127).

A personalidade humana possui função psicanalítica, ou seja através do ato de sonhar, por meio da rêverie/função alfa, é capaz de elaborar vivências emocionais, consciente e inconscientemente. A função psicanalítica da personalidade manifesta-se no ato de sonhar que, para Bion, acontece em período de sono e de vigília:

\footnotetext{
Sonhar é um processo constante que ocorre tanto no sono quanto na vida de vigília inconsciente. Se uma pessoa é incapaz de transformar impressões sensórias brutas em elementos inconscientes da experiência que possam ser ligados, ela é incapaz de gerar pensamentos-sonho inconscientes e, consequentemente, não pode sonhar (seja durante o sono ou na vida de vigília inconsciente). A experiência de impressões sensórias brutas (elementos-beta) no sono não é diferente da experiência de elementos-beta na vida de vigília. (Ogden, 2010, p. 19)
}

O sujeito vive uma experiência emocional e sonha como forma de responder e elaborar a experiência emocional, tornando a experiência consciente disponível para o inconsciente. O crescimento psicológico depende do trabalho psicológico realizado a partir do que se viveu.

Identificação projetiva pode ser estudada em suas dimensões intrapsíquica e interpessoal, sendo um processo psicológico que é, ao mesmo tempo: i) um tipo de defesa, sendo utilizada como forma de afastamento dos sentimentos rejeitados; ii) um modo de comunicação, em que sentimentos são induzidos em outra pessoa, criando-se a ideia de poder ser compreendido pelo outro; iii) uma forma primitiva de relação de objeto com objetos parcialmente separados; e iv) um caminho para 
transformação psicológica, através do processamento pelo receptor de sentimentos com os quais o projetor não consegue lidar, e da disponibilização destes sentimentos de forma modificada para reinternalização.

Estas funções da identificação projetiva remetem às tentativas da criança de perceber, organizar e manejar suas experiências internas e externas e se comunicar com o ambiente. A mãe suficientemente boa auxiliará a criança a organizar suas experiências. O splitting é um modo primitivo de organização e defesa: a criança mantém separadas experiências ruins de experiências reconfortantes. Apesar de Winnicott raramente ter utilizado em sua obra o termo “identificação projetiva”, ele muito refletiu sobre a identificação projetiva e suas consequências para o desenvolvimento normal ou patológico do bebê (Ogden, 2010).

Adentrando na preocupação materna primária (Winnicott, 1956/2000b), estado de grande sensibilidade afetiva, a mãe é capaz de identificar-se com o bebê, antecipando suas necessidades. É nesse contexto que se inicia o processo de identificação projetiva, tanto como defesa como forma de comunicação. A identificação projetiva auxilia a criança na tentativa de manter distante o que é sentido como bom do que é sentido como mau. Ao depositar no outro aspectos de si, a criança mantém contato tanto com o que foi projetado quanto com o outro.

A identificação projetiva opera em termos de comunicação interpessoal quando a criança, incapaz de colocar em palavras seus sentimentos, induz o outro a se sentir como ela se sente. Além disso, a identificação projetiva é um tipo primitivo de relação de objeto, uma forma de estar com um objeto apenas parcialmente separado. Uma forma transicional de relação de objeto, que se situaria entre o estágio de objeto subjetivo e a verdadeira relação de objeto.

A capacidade de manejo da identificação projetiva é importante, tanto para a mãe, quanto para o analista e para a equipe de saúde da UTI Neonatal. A mãe pode ser incapaz de um manejo suficientemente bom quando a criança projeta sentimentos destrutivos através da interação da dupla. Quando não pôde resolver seus próprios conflitos em relação a sentimentos destrutivos, a mãe pode apresentar dificuldades em lidar com tais sentimentos projetados. A criança pode tornar-se alvo do ataque da mãe e algumas reações possíveis seriam: afastamento excessivo, hostilidade, descuido perigoso em relação à criança. Por outro lado, havendo medo ou culpa da mãe em relação aos sentimentos destrutivos, pode 
haver uma superproteção da mãe com a criança, impedindo qualquer afastamento da dupla. Com o intuito de salvaguardar a criança, há a possibilidade também da mãe projetar os sentimentos em outros pessoas ao redor.

Assim, o manejo suficientemente bom passa pela aceitação, mesmo inconscientemente, da mãe de seus próprios sentimentos. Esta fase de integração psicológica é a fase do processamento da identificação projetiva. Através das interações mãe-criança, a projeção processada ficaria à disposição da criança para reinternalização.

A capacidade de manejo suficientemente bom dos sentimentos projetados pela criança no adulto é o caminho para um crescimento psicológico e envolveria a capacidade materna de integrar os sentimentos produzidos pela criança com aspectos próprios, como por exemplo:

\footnotetext{
seu egoísmo saudável, sua aceitação pelo seu direito de estar brava e ressentida em relação ao seu filho por atrapalhar o que ela deseja, sua segurança em ser capaz de conter tais sentimentos sem atuar sobre eles com afastamentos excessivos ou ataques retaliatórios. (Ogden, 2010, p. 24)
}

Nesse sentido, é importante ter em mente que a ambivalência está presente nas relações humanas. Não é possível tanto pais, quanto profissionais, cuidarem de um bebê sem ambivalência: "Não podemos nos ocupar do bebê sem ambivalência, pois não há amor sem ambivalência nem para os pais, nem para os profissionais. O bebê não é todo rosa bombom" (Golse, 2003, p. 23).

Em seu artigo "O ódio na contratransferência" (1947/2000a), Winnicott traz 23 razões para uma mãe odiar seu bebê. Golse acredita que Winnicott tenha sido muito generoso, pois haveria bem mais do que 23 razões para uma mãe odiar seu bebê.

Ao conceituar identificação projetiva, Ogden (2010) descreve uma sequência de três fases, no entanto, trata-se de um único evento psicológico e as três fases devem ser compreendidas como ocorrendo simultaneamente e em interdependência uma da outra.

Na primeira fase, há o desejo do sujeito de livrar-se de uma parte do self, incluindo-se os objetos internos. Esclarece o autor que isso aconteceria por dois motivos: a) a parte projetada ameaça destruir o self; ou b) uma parte do self está em perigo, podendo ser atacada por outras partes do self e, assim, ao ser projetada, a parte estaria segura do ataque. 
Na segunda fase, o projetor exerce pressão no receptor para que aja em consonância com suas fantasias projetivas. Não se trata de pressão imaginária, mas de uma pressão real que se dá através das interações receptor-projetor: “identificação projetiva não existe onde não há interação entre projetor e receptor" (Ogden, 2010, p. 11).

$\mathrm{Na}$ terceira fase, o receptor percebe-se em parte como ele é imaginado na fantasia projetiva do projetor. O receptor experiencia seus próprios sentimentos, que podem ser parecidos, mas não idênticos, aos do projetor: "Apesar de sentimentos provocados por um tipo muito específico de pressão do projetor, eles são produtos de um sistema de personalidade diferente, com diferentes pontos fortes e fracos" (Ogden, 2010, p. 17). Desta forma, abre-se a possibilidade de o receptor lidar com esses sentimentos projetados de forma diferente da qual o projetor foi capaz de lidar. Lidando de forma distinta da qual o projetor foi capaz de lidar, o receptor produz novos sentimentos. Este processamento psicológico pelo receptor pode ser incompleto e contaminado pela patologia do receptor.

$\mathrm{O}$ receptor digere sentimentos antes rejeitados e torna disponível para internalização (ou reinternalização) essa nova gama de sentimentos gerada, através da interação projetor-receptor. São o processamento da projeção e a reinternalização que oferecem ao projetor novas formas de lidar com sentimentos e, consequentemente, promovem crescimento psicológico do projetor:

Qualquer que seja a forma do processo de reinternalização, ele oferece ao projetor o potencial para alcançar novas forma de lidar com sentimentos antigamente rejeitados. $\mathrm{Na}$ medida em que a projeção é processada com sucesso e reinternalizada, um genuíno crescimento psicológico aconteceu. (Ogden, 2010, p. 18)

Podemos pensar a identificação projetiva como positiva ou negativa. A identificação projetiva seria positiva quando possui função de comunicação ao analista-continente, com prognóstico positivo; e negativa quando possui apenas função de evacuação das partes ruins do eu, colocando em risco a análise em função dos actings out violentos direcionados ao analista. A análise, através da identificação projetiva positiva, pode retomar e transformar as falhas de uma tentativa de projeção em um objeto externo. Por outro lado, a pressão externa exercida do analisando no analista poderá ter caráter violento, expondo as dificuldades contratransferenciais do analista em lidar com a identificação projetiva (Gibeault, 2000). 
Soubieux (2013) acredita que seu trabalho como analista, tanto na maternidade, como no consultório recebendo pacientes que sofreram perdas gestacionais ou neonatais, é justamente o de dar ao paciente a possibilidade de transformar os elementos beta em elementos alfa. A autora relata o caso de uma paciente que havia sofrido uma interrupção médica da gestação (IMG). A paciente chegou ao seu consultório dois anos após a IMG. Seus relatos eram tão vivos e precisos como se a IMG tivesse acabado de ocorrer. Durante a entrevista, Soubieux percebe, por identificação projetiva, que a paciente lhe havia feito viver o horror e a angústia pela qual ela havia sido invadida. Acolhendo o que veio da paciente, a autora pôde ouvir sua raiva e sua rejeição em relação ao feto, sem que a paciente se sentisse julgada ou abandonada em seguida. Ao final da sessão, Soubieux teve a impressão de que tudo o que aterrorizava a paciente e que ela não havia podido dizer ao longo dos anos foi se tornando menos assustador. Inclusive transformações corporais puderam ser observadas ao final da sessão: seu olhar se descontraiu, sua voz se suavizou e seu corpo relaxou.

O conceito de identificação projetiva não está atrelado a nenhuma concepção cronológica de desenvolvimento, havendo apenas dois requisitos para sua ocorrência: (a) o projetor, sendo ele bebê, criança ou adulto, normalmente com forma muito rudimentar de simbolização, ter capacidade para fantasia projetiva e formas específicas de relação com objetos para as fases de indução e reinternalização da identificação projetiva - pensemos, por exemplo, no congelamento psíquico que pode ocorrer com os pais diante das situações gravíssimas experienciadas na UTI Neonatal, como iminência de morte de seu bebê -; e (b) a capacidade do receptor da projeção em se envolver em determinada forma de relação de objeto para que possa receber, digerir e processar a projeção (Ogden, 2010).

Refletindo sobre as implicações técnicas e teóricas da identificação projetiva, Ogden (2010) sugere que o terapeuta, diante da identificação projetiva do analisando, não tenha nada a fazer além de procurar vivenciar os afetos produzidos pelo analisando. Sem negar ou tentar se livrar, o terapeuta deve procurar viver com tais sentimentos produzidos pelo paciente, estando disponível para receber a projeção e conter os sentimentos do paciente. Soubieux (2013), no caso relatado acima, ressalta como seu acolhimento e escuta empática enquanto 
analista, puderam favorecer o afrouxamento das defesas e a diminuição da angústia de sua paciente.

É importante ter em mente que o terapeuta, assim como os membros da equipe de saúde de UTI Neonatal, são seres humanos com suas dificuldades pessoais e não recipientes vazios onde podem ser depositadas identificações projetivas. Os sentimentos com os quais o paciente está precisando lidar são difíceis e com grande carga emocional para o terapeuta também. O mesmo ocorre com a equipe de saúde que acompanha os pais e os bebês internados na UTI Neonatal. Espera-se que, pela maior integração pessoal do terapeuta, ele tenha mais capacidade e menos medo de lidar com tais sentimentos. Citando Winnicott, Ogden (2010) diz que, da parte do terapeuta, o manejo dos sentimentos projetados requer esforço, habilidade e tensão.

São ferramentas para compreender e conter a identificação projetiva a formação teórica, a análise pessoal e a experiência. No que se refere à equipe de saúde de UTI Neonatal, que não possui formação teórica específica da Psicanálise, como compreender e conter a identificação projetiva dos pais? Abordaremos este ponto no capítulo subsequente.

Nem sempre a compreensão pelo terapeuta da identificação projetiva deve ser verbalizada para o paciente. Uma interpretação que pareça correta e no tempo certo para o terapeuta, pode ser na hora errada para o paciente. Assim, uma interpretação silenciosa pode ser formulada na cabeça do terapeuta e não verbalizada para o paciente: “uma autoanálise contínua possui valor inestimável na tentativa de um terapeuta lidar com, conter e crescer a partir dos sentimentos do paciente ejetados nele" (Ogden, 2010, p. 31).

Como forma de suportar suas próprias defesas, o terapeuta pode valer-se de desvios na técnica, vindo a falhar na contenção da identificação projetiva. São violações de regras básicas da Psicoterapia e da Psicanálise: levar a relação para um contexto social, dar presentes ao paciente e encorajá-lo que também o faça, ou violar a confidencialidade. A falha no processamento da identificação projetiva aparece na resposta do terapeuta de duas maneiras: a) estabelecimento de rígida defesa contra a consciência dos sentimentos produzidos pelo paciente; e b) permitindo que o sentimento ou a defesa contra o sentimento seja convertido em ação. Essas falhas fazem com que o paciente reinternalize os sentimentos originais projetados no terapeuta e o medo do terapeuta e o manejo inadequado de tais 
sentimentos. O resultado é que os medos e as defesas patológicas do paciente são reforçadas (Ogden, 2010).

Deve-se estar atento também às identificações projetivas do terapeuta, que exercem pressão no paciente. Ogden (2010) cita como exemplo quando o terapeuta deseja que seu paciente "se cure" e pressiona-o para que se comporte como um paciente curado. Um paciente mais saudável pode recusar-se a agir assim, no entanto, em casos mais graves, o paciente pode aceitar a incumbência ou revoltar-se contra a pressão e terminar a análise. Nesse sentido, não podemos nos esquecer que há a identificação projetiva da equipe de saúde da UTI Neonatal, que exerce pressão nos pais, mas infelizmente, ainda que muito relevante o tema, não abordaremos tal ponto no presente estudo.

Pais e terapeutas não têm apenas sentimento de cura e crescimento em relação a seus filhos e pacientes, respectivamente. Há também sentimentos de ódio e aniquilamento, que devem ser integrados por pais e terapeutas para que não sejam atuados, negados ou projetados. Quando o terapeuta reconhece a existência de identificação projetiva incessante, deve prudentemente avaliar seu estado psicológico e reconsiderar terapia pessoal (Ogden, 2010).

A partir da teoria exposta acima em relação à identificação projetiva, especialmente no que se refere à metáfora bioniana continente-conteúdo, inspirada no modelo de relação existente entre a mãe e seu bebê, e que serviu de base para refletir sobre a relação analista-analisando, nós pretendemos estender esse modelo para a relação equipe de saúde-pais dos bebês internados na UTI Neonatal. A equipe seria receptora da identificação projetiva dos pais e responsável pela transformação dos elementos beta em elementos alfa, disponibilizando-os para a reintrojeção dos pais. Pretendemos analisar a vinheta clínica abaixo e pensar nas possibilidades de manejo suficientemente bom pela equipe-receptora da identificação projetiva.

\section{1}

\section{Vinheta clínica: morte e identificação projetiva}

Confrontados com o drama de ter seu bebê hospitalizado em uma UTI Neonatal, os pais podem viver um momento de caos psíquico e ter a sua capacidade de pensar afetada. A equipe de saúde da UTI Neonatal, 
emocionalmente disponível para os pais, desempenha um papel fundamental no acolhimento deles durante a internação do bebê.

Por esse motivo, acreditamos que o conceito de identificação projetiva pode ser aplicado às situações vividas na UTI Neonatal e a equipe de saúde seria a receptora (equipe-continente) da projeção dos pais. Enquanto destinatária dos afetos, muitas vezes desorganizados, da família, a equipe de saúde pode ocupar a função de conter e transformar a experiência vivida pelos pais em pensamentos e sentimentos que possam ser integrados aos seus psiquismos.

A vinheta clínica apresentada abaixo pode nos auxiliar a refletir sobre as experiências vividas na UTI neonatal.

$\mathrm{Na} 36^{\mathrm{a}}$ semana gestacional, Betina deu entrada na maternidade para dar a luz a seu bebê, Pedro, que no pré-natal havia recebido o diagnóstico de síndrome de Edwards. Considerada na literatura médica uma "síndrome incompatível com a vida", quando não ocorre um aborto espontâneo durante a gestação, a sobrevida dos bebês com síndrome de Edwards é de 2,5 a 14,5 dias.

Betina fez seu acompanhamento pré-natal da gestação em outra cidade e veio para uma maternidade privada exclusivamente para o nascimento do bebê, pois a UTI Neonatal desta maternidade é reconhecida por sua excelência. Isto significa que tomamos conhecimento do caso de Betina poucas horas antes dela dar à luz ao seu filho Pedro. Estivemos em seu quarto na maternidade para saber sobre seu estado emocional diante da proximidade do parto e para dizer que esperávamos revê-la em breve na UTI Neonatal quando o bebê tivesse nascido.

Nesta primeira entrevista, conhecemos um pouco da história de Betina e de Pedro. Betina já tinha um filho, adulto jovem, de um relacionamento anterior. Seu companheiro, pai de Pedro, a abandonou durante a gestação ao tomar conhecimento que o bebê havia síndrome de Edwards. Diante deste abandono paterno, Betina veio para a maternidade acompanhada apenas da avó materna de Pedro. Constantemente alertada pelos médicos sobre o risco de morte de Pedro, Betina conta na primeira entrevista que, durante a gestação, procurou fazer muitos passeios com Pedro ainda em sua barriga, pois não sabia se seria possível realizar estes passeios com ele em seus braços. Betina estava tensa, mas procurava se mostrar confiante com a proximidade do parto. Ela torcia para que, a partir do momento que cortassem o cordão umbilical, o coração de Pedro fosse forte e que ele pudesse reagir. 
Tendo convivido com o prenúncio da morte de seu bebê durante toda a gestação, Betina veria seu filho nascer. Devido às inúmeras malformações, após o parto, Pedro foi encaminhado diretamente para a UTI Neonatal. Em 48 horas seu quadro era gravíssimo. Pedro estava morrendo quando a enfermeira Helena se aproximou de Betina, dizendo que, se assim desejasse, poderia segurar seu filho nesses últimos momentos. Helena ressaltou que Betina não era obrigada a segurar seu bebê nos braços, mas ela poderia fazê-lo se sentisse que isso the faria bem. Alguns estudos (Soubieux, 2013) demonstram que o fato dos pais acompanharem seu bebê no processo de morrer permite-lhes acessar seus sentimentos e iniciar um trabalho de luto sem tanta ambivalência e negação.

Os demais membros da equipe de enfermagem desaprovavam a atitude de Helena, pois o bebê faleceria no colo da mãe. Tinham medo de o bebê morrer no colo da mãe e que fossem obrigados a presenciar essa cena. E se a mãe se desesperasse? Talvez alguns membros da equipe fantasiassem, inconscientemente, que, no intuito de se protegerem dos sentimentos fortes a que eles próprios estariam sujeitos, seria melhor deixar o bebê morrer e depois chamar a mãe para vê-lo.

Na UTI Neonatal a qual nos referimos, os leitos dos bebês estão dispostos em um amplo salão, respeitada a distância segura entre uma incubadora e outra, diferentemente do que ocorre em outros serviços, como no Hospital Necker Enfants Malades, em Paris, onde cada bebê está em um quarto da UTI Neonatal. Assim, quando morre um bebê em nosso serviço e, na falta de um lugar para levar a família e o corpo do bebê, pede-se aos outros pais que saiam da UTI para que a família que acabou de perder seu bebê tenha um pouco de privacidade antes do bebê ser encaminhado para o quarto mortuário.

Certamente, essa não é a situação ideal para nenhum dos envolvidos: os outros bebês ficarão privados da companhia de seus pais; os pais que perderam seus bebês terão um tempo reduzido para se despedir de seu bebê; e a equipe terá que gerenciar os eventuais conflitos que daí surgirem. Este é mais um dado para pensar no tênue equilíbrio a que está sujeita a equipe de saúde: garantir um espaço para que a família possa despedir-se do bebê morto e reabrir a UTI Neonatal para os outros pais.

Posteriormente, depois da morte de Pedro, Helena foi alvo da ira materna, quando precisou retirar o bebê, já falecido, do colo da mãe. Betina descarregou na 
enfermeira seus sentimentos hostis e negados por ela, em relação ao que estava vivendo desde o momento da descoberta da síndrome genética de seu bebê: a concepção de um bebê sindrômico, o abandono paterno no início da gestação, e o nascimento de seu filho com uma síndrome "incompatível com a vida".

Quando a enfermeira fez menção de retirar o bebê do colo materno, a mãe ficou irada e estava começando a agredir a enfermeira com palavras. A enfermeira Helena, por sua vez, se assustou com a agressividade materna. Neste instante, pudemos traduzir para a mãe o que estava sendo dito pela enfermeira. Nós explicamos para a mãe que era necessário desconectar o bebê dos monitores e aparelhos e preparar seu corpo para que a mãe pudesse ficar com ele em outro local que não fosse dentro da UTI Neonatal. A mãe conseguiu acalmar-se e entregar o bebê para a enfermeira. Sentimos que nossa atitude serviu, inclusive, para acalmar a enfermeira.

Nestas situações extremas de acompanhar seu bebê no processo de morrer, a agressividade está muitas vezes presente, exigindo grande disponibilidade psíquica do profissional de saúde. Talvez a enfermeira estivesse esperando gratidão por proporcionar que Betina segurasse seu bebê pela última vez, ainda com vida:

Quanto aos profissionais, eles têm uma certa onipotência em razão dos meios hípersofisticados de que dispõem, mas estão às vezes desarmados face às reações paradoxais dos pais. Podem esperar um reconhecimento e encontram às vezes raiva, até mesmo ódio, ou ao contrário, uma total submissão. Pesa sobre eles nessa situação de crise, o peso do indizível e do intolerável. (Druon, 1999, p. 37)

No momento do óbito de Pedro, a maternidade ainda não possuía um quarto próprio que pudesse acolher uma família para despedir-se de seu bebê. A disponibilização de um espaço específico para tal encontro foi um resultado alcançado pelo trabalho da equipe multidisciplinar que passou a estudar formas de acolher o óbito na maternidade e na UTI Neonatal.

Quando do falecimento de Pedro, a psicóloga e a enfermeira Helena solicitaram à gerência a disponibilização de um quarto para que Betina e a avó materna pudessem passar mais um tempo com Pedro. Helena explicou a Betina que ela iria preparar o corpo do bebê e indagou à mãe se ela gostaria de ir para este quarto, que estaria disponível, se Betina assim o desejasse, para continuar mais um tempo com seu bebê. Betina e a avó materna dirigiram-se para este quarto e aguardaram a chegada do corpo de Pedro. Lá ficaram por algumas horas, 
nas quais Betina pôde embalar Pedro nos braços e lhe falar baixinho. Durante alguns momentos a psicóloga esteve presente no quarto onde estavam Betina, Pedro e a avó materna, conversando e acolhendo Betina, mas sem invadir o espaço da mãe que queria estar com seu bebê.

A equipe de Psicologia acompanhava a cena dentro da UTI Neonatal e pôde intervir em três momentos: no primeiro momento, dando suporte para Helena colocar o bebê no colo materno, já que esse era o desejo da mãe, ainda que contrariando os demais membros da equipe. Em um segundo momento, ainda dentro da UTI Neonatal, no momento em que a enfermeira precisava retirar o bebê do colo da mãe, traduzindo as palavras da enfermeira para Betina. E em um terceiro momento, após o óbito, com a mãe e com a enfermeira, separadamente, para que pudéssemos acolher os sentimentos de ambas relacionadas à morte do bebê.

Para a enfermeira, pudemos traduzir a revolta materna e refletir sobre seus sentimentos. Juntas, pensamos que a morte de um bebê é da ordem do inominável. Um filho, quando perde os pais, torna-se órfão. Não há palavra para nomear uma mãe que perde seu filho. É um momento de caos psíquico, em que o ódio, a cólera, a tristeza e o horror estão presentes. Betina precisava depositar estes sentimentos insuportáveis em alguém, e Helena foi, naquele instante, justamente por ter posto o bebê no colo da mãe, a pessoa que estava lá para recebê-los. Era pesado demais para esta mãe lidar com tais sentimentos naquele momento e eles foram depositados, por identificação projetiva, na enfermeira.

Em relação à função do psicólogo em UTI Neonatal, concordamos com Druon (1999) quando diz seu papel é de intermediador: "É aí que se situa a função de amortizador de conflitos e o papel de intermediador" (p. 43) Foi o que procuramos fazer na vinheta apresentada acima, intermediando a relação para que a situação não ficasse ainda mais penosa do que já era.

O trabalho de suporte à equipe de saúde é, muitas vezes, um trabalho de interstício, de corredor, de encontros e trocas informais, de acordo com o que cada membro traz para ser discutido com a psicóloga. Como já foi dito anteriormente, infelizmente, não há em nosso serviço um grupo de fala ou, para usar o termo utilizado por Séguret (2013), a hora de pausa, ou ainda uma reunião de síntese como propõe Mathelin (1999), para que a equipe de saúde possa refletir e expressar seus sentimentos acerca das experiências vividas dentro da UTI 
Neonatal. No entanto, parece-nos fundamental, com o devido apoio da instituição, a realização de um trabalho voltado para o acolhimento e suporte da equipe de saúde, especialmente quando se trata de compreender seus próprios sentimentos diante da morte de um bebê e os mecanismos da identificação projetiva.

Diante das situações vividas na UTI Neonatal - um bebê real muito diferente do bebê imaginado; um bebê pouco responsivo aos pais e, por isso, incapaz de parentalizá-los; a fragilidade da vida do bebê e a constante confrontação entre vida e morte a que estão sujeitos -, os pais dos bebês internados, como modo de comunicação primitiva, projetam na equipe de saúde conteúdos maus relacionados às vivências da UTI Neonatal, como o que aconteceu na vinheta clínica. Betina, impossibilitada de lidar com o horror do momento de morte do seu filho, projetou seus sentimentos na enfermeira Helena.

Precipitados neste ambiente hostil, os pais podem ter sua capacidade de pensamento afetada e dependeriam da capacidade onírica da equipe de saúde da UTI Neonatal para receber e metabolizar a identificação projetiva, transformando os elementos beta em elementos alfa. Soubieux (2013) afirma que a forma como a equipe consegue estar com os pais nesse momento particular de drama é fundamental para a evolução posterior, tanto em caso de morte do bebê como no caso em que o bebê sobrevive. Reflitamos sobre o momento de óbito de Pedro, na possibilidade da mãe segurar seu filho nos braços e no quarto disponibilizado pela instituição para prolongar o momento de despedida. Acreditamos que a forma como a enfermeira Helena encontrou de estar com a mãe no momento da morte de Pedro poderá possibilitar um luto de melhor qualidade para Betina.

A equipe de saúde da UTI Neonatal muitas vezes desempenha a função de continente para a projeção de um conteúdo parental. Nesse sentido, a identificação projetiva poderá ter função positiva quando se tratar de comunicação à equipecontinente. A mãe depositou na enfermeira seus sentimentos, a qual serviu de continente para a ira materna. No caso apresentado acima nós tentamos demonstrar a identificação projetiva da mãe sobre a enfermeira quando Helena foi o alvo da cólera materna no momento em que Helena precisou retirar Pedro, já sem vida, dos braços de sua mãe.

Em um primeiro momento, a enfermeira Helena identificou-se com o que foi projetado por Betina. Tendo sido capaz de dar-se conta que os sentimentos projetados não eram seus, Helena pôde compreender de maneira mais próxima os 
sentimentos de Betina. Posteriomente, Helena foi capaz de digerir os sentimentos e transmiti-los à Betina de maneira metabolizada, para que a mãe pudesse, enfim, entrar em contato com esses afetos.

Todo o componente agressivo que sentia dentro de si durante toda a gestação de risco e a raiva que sentia por seu filho não ter sobrevivido, foram despejados sobre a enfermeira. Isso aconteceu por duas razões: a) a parte projetada ameaçava destruir o eu; ou b) uma parte do eu estava em perigo, podendo ser atacada por outras parte do eu, assim, a partir do momento em que ela é projetada, ela estará protegida de qualquer ataque.

Apesar de ter sido difícil para a enfermeira receber as palavras violentas da mãe, ela conseguiu absorver as palavras e não reagir de pronto. Além disso, a enfermeira, após nossa reflexão em dupla sobre o que estava acontecendo na relação mãe-enfermeira, não retaliou a mãe, deixando, por exemplo, de solicitar à Direção da maternidade um quarto para que a mãe pudesse continuar a se despedir de seu bebê.

Por outro lado, a identificação projetiva teria sido negativa se tivesse servido apenas para evacuação das partes ruins da mãe, colocando em risco a relação equipe de saúde-mãe. Apenas como exercício de reflexão, a partir da vinheta clínica acima, entendemos que a identificação projetiva teria sido ruim caso a mãe tivesse apenas evacuado suas partes ruins e se a enfermeira não tivesse tido capacidade de contenção para a ira materna. Desta forma, a enfermeira teria simplesmente reagido ao ouvir as palavras violentas da mãe e, consequentemente, o cuidado com o bebê e os últimos cuidados com a mãe poderiam ter sido afetados.

Para que o manejo da identificação projetiva dos pais pela equipe da UTI Neonatal seja suficientemente bom, a equipe deve ser capaz de lidar com seus próprios sentimentos hostis e de destrutividade, sentimentos relacionados à morte dos bebês e o que isso evoca: a nossa própria finitude.

A equipe de saúde da UTI Neonatal necessita digerir seus próprios sentimentos em relação às experiências vivenciadas. Pensemos, por exemplo, na equipe de enfermagem que se posicionou contrariamente a colocar o bebê no colo da mãe para que pudesse falecer em seus braços. Não fosse a grande mobilização que aconteceu - o posicionamento da enfermeira, a aprovação da médica de plantão e o nosso suporte -, talvez Betina não tivesse segurado seu filho nos 
últimos minutos ainda com vida. Acreditamos que a equipe tenha se posicionado de maneira contrária, pois, para a equipe de saúde, também é difícil ver um bebê morrer. A equipe de saúde é composta por seres humanos, que possuem uma história pessoal única.

No próximo capítulo, refletiremos sobre a possiblidade de manejo da equipe-receptora em relação à identificação projetiva. $\mathrm{O}$ melhor acolhimento do bebê e de sua família inicia-se com um trabalho de suporte e acolhimento dos aspectos emocionais da equipe de saúde. Assim, a reflexão sobre o sofrimento psíquico a que estão sujeitos os membros da equipe de saúde torna-se fundamental.

Considerando o ambiente da UTI Neonatal potencialmente traumático, inclusive para a equipe de saúde, no capítulo seguinte abordaremos as funções antitraumáticas que podem ser colocadas em prática neste ambiente, como forma de elaborar as experiências emocionais. 


\section{4 \\ Funções antitraumáticas na UTI Neonatal}

Considerando o ambiente da UTI Neonatal potencialmente traumático para a equipe de saúde, questionamos: como é possível manter-nos psiquicamente vivos neste ambiente onde a morte de um bebê é uma ameaça constante? No presente capítulo, pretendemos refletir sobre o holding (Winnicott, 1975) e a continência e rêverie (Bion, 1962), que podem ser colocados em prática no e pelo ambiente da UTI Neonatal para que a morte psíquica não prevaleça sobre a morte do corpo.

Holding e contenção são funções essenciais da "intersubjetividade transubjetiva", figura de alteridade descrita por Figueiredo (2007) na "teoria geral do cuidar", possuindo funções específicas que auxiliarão no exercício da função do agente de cuidado. Cintra (2003), ao descrever a função materna, aponta os aspectos antitraumáticos do holding e da contenção. Segundo a autora, a função materna possui aspectos antitraumáticos, permitindo que o sujeito lide com as agonias impensáveis ao promover estabilidade mental e ligações importantes para seu desenvolvimento físico e psíquico. Um cuidador, que cumpre funções antitraumáticas, permite um bom funcionamento psíquico, auxiliando o sujeito a superar as dificuldades que se apresentam.

Concordamos com a autora quando diz que estes aspectos antitraumáticos não estão restritos à vida do bebê e à infância. Winnicott, em sua obra, já comparava as funções maternas primárias às funções do analista (Cintra, 2003). Quando pensamos no trabalho realizado pela equipe de saúde da UTI Neonatal, onde as defesas do sujeito estão ameaçadas pelos excessos do ambiente e pela constante ameaça de morte dos bebês, torna-se fundamental refletir sobre funções antitraumáticas a serem postas em prática.

O holding proporciona o sentimento de continuidade de existência do ser, sendo que no início da vida essa sustentação é dada por aquele que exerce a função materna. O conceito de holding tem como ponto central o ser e a sua relação com o tempo. "Continuar a ser" foi a expressão utilizada por Winnicott (1975; Davis 1982) para definir a experiência de sentir-se vivo. O holding materno refere-se à sustentação física e psicológica do bebê, sendo a sua principal 
função garantir ao bebê que o tempo seja medido no seu ritmo e não no tempo inventado pelo homem com minutos, horas e semanas. Os ritmos do bebê "incluem os ritmos de sua necessidade de sono e de vigília, de sua necessidade de envolvimento com outrem e de sua necessidade de isolamento, os ritmos de fome e saciedade, os ritmos de respiração e batimentos cardíacos" (Ogden, 2010, p. $123)$.

$\mathrm{Na}$ medida em que o bebê cresce, o holding materno vai sendo internalizado, e o bebê passa a ter a experiência dos fenômenos transicionais e da capacidade de estar só. O sujeito começa a ser capaz de lidar com um tempo que lhe é externo e começa a ser capaz de se automaternar. A qualidade e a intensidade da troca afetiva entre o bebê e sua mãe são o fundamento para a constituição psíquica do bebê e influenciará a forma como ele se colocará no mundo.

A vida humana está longe de ser uma calmaria, perfeita e estável. Ao longo da vida, inevitavelmente acontecerão excessos traumáticos, que precisarão fazer sentido para o sujeito. "Fazer sentido implica estabelecer ligações, dar forma, sequência e inteligibilidade aos acontecimentos" (Figueiredo, 2007, p. 15). $\mathrm{O}$ ser humano precisa dar sentido à sua vida e às dificuldades que vivenciará durante sua existência. A experiência de integração dos excessos da vida será exercida, ensinadas e facilitadas no início da vida pelos agentes de cuidados, para que depois possam, gradualmente, ser exercidas pelo sujeito.

Diante da ameaça constante de "sem-sentido" na vida, o ser humano tem necessidade de continuamente "fazer sentido" (Figueiredo, 2007). Na UTI Neonatal, tanto os pais como a equipe têm necessidade de "fazer sentido" do que vivenciam. Diante de um parto prematuro, muitas mães questionam a razão de têlo sido, culpam-se por não terem conseguido "segurar" a gestação. Já a equipe, por exemplo, tem necessidade de dar sentido à morte dos bebês que não puderam ser salvos, apesar de toda a tecnologia e de todos os esforços.

A contenção garante experiências de transformação, de crescimento, de expansão. Para ambas as experiências de continuidade e de transformação, é fundamental a presença implicada do outro. Ao longo da vida, em momentos de maior dificuldade, todos os sujeitos precisam de alguém para realizar essas tarefas de sustentação e continência. Na UTI Neonatal, a necessidade da presença 
implicada do outro para sustentar e conter ficam evidentes diante do desamparo do profissional que acompanha a prematura morte de um bebê.

O conceito bioniano de continente está relacionado ao processamento da experiência emocional vivida. Refere-se à forma como pensamos, "como processamos a experiência vivida e o que ocorre psiquicamente quando somos incapazes de fazer um trabalho psicológico com aquela experiência" (Ogden, 2010, p. 127).

$\mathrm{O}$ ato de sonhar possibilita a elaboração das vivências emocionais pelo sujeito, permitindo que, a partir de determinada experiência emocional, realize trabalho psicológico como forma de resposta e de elaboração à experiência emocional. O crescimento psicológico é resultado do trabalho psicológico realizado a partir do que se viveu (Bion, 1962).

No início da vida, o bebê não é capaz de digerir a experiência emocional vivida por si só. É necessária a presença implicada da mãe, que, emocionalmente disponível para o bebê, realizará o trabalho psicológico de sonhar e devolverá para o bebê a experiência emocional de forma tolerável para que, então, ele possa sonhá-la. Se, no início da vida, certamente há a necessidade da presença implicada do outro para poder sonhar, ao longo da vida, o sujeito pode passar por experiências emocionais que o reenviam a este estado de necessitar da presença implicada de um outro para poder sonhar.

Pensemos, então, no agente do cuidado. Dependendo da intensidade da experiência emocional vivida, pode ser que haja a necessidade de o cuidador ser cuidado por um terceiro. A mãe, que dá sustentação ao bebê, deve se permitir receber a sustentação de sua própria mãe ou de seu marido, renunciando assim a sua própria onipotência. Da mesma forma, acreditamos que os membros da equipe de saúde da UTI Neonatal precisam ser cuidados pela instituição. O reconhecimento de seus próprios limites sensibiliza o cuidador para as necessidades do objeto de cuidado: "é preciso saber cuidar do outro, mas também cuidar de si e... deixar-se cuidar pelos outros, pois a mutualidade nos cuidados é um dos mais fundamentais princípios éticos a ser exercitado e transmitido" (Figueiredo, 2007, p. 21).

Cuidar é uma atividade inerente a todos os seres humanos. O agente de cuidados é aquele que "faz coisas" pelo sujeito, mas também se coloca como presença em reserva. O mais importante da presença reservada do agente de 
cuidados é permitir o surgimento do que Winnicott (1975) denominou de espaço potencial ou, como denominado por Figueiredo (2007), um espaço vital desobstruído da presença do cuidador. A tarefa do cuidador é proteger esse espaço potencial, permitindo ao objeto de cuidado exercitar sua criatividade.

Pensemos na UTI Neonatal, um ambiente com excessos traumáticos e a ameaça de muitas experiências sem-sentido. É importante dar tempo e espaço para que as fantasias inconscientes do sujeito possam emergir. A proposta de um grupo de fala coordenado por uma psicóloga ou, como denomina Séguret (2013), a hora de pausa, pode ser um espaço de sustentação e contenção para a equipe de saúde. A troca promovida pelo grupo pode ajudar a "fazer sentido" dos acontecimentos. São dois os elementos oferecidos pelo grupo de fala: o holding, que permite a continuidade simbólica do sujeito; e a continência, que possibilita a transformação, isto é, “crescer, expandir-se, se possível sem rupturas excessivas mas também sem meras repetições" (Figueiredo, 2007, p. 17).

Desta forma, o trabalho do psicólogo na UTI Neonatal pode ter função de paraexcitação, de contenção e de dar sentido, trabalho que se realiza junto aos pacientes, mas também junto à equipe de saúde, remetendo à imagem do "olho do ciclone": um espaço/tempo de calma no meio do furacão (Alvarez, Yamgnane, Parat, Benachi, Vion, Dugué, Beauquier-Maccotta \& Simas, 2012, p. 101).

Como dito anteriormente, o trabalho de suporte oferecido pela psicóloga à equipe de saúde é apontado por Séguret (2013) como um trabalho de interstício, de corredor, de encontros e trocas informais. Pretendemos abordar os três pontos que podem nos auxiliar na compreensão da função antitraumática. São eles: os pesadelos relacionados ao serviço, os grupos de fala e o filme "Sara".

No serviço em que atua Séguret (2013), semanalmente há um grupo de fala nomeado por ela de "hora de pausa", composto pela equipe de saúde que permite a escuta e a simbolização das emoções negativas. Esse tipo de trabalho possibilitou que a equipe se desse conta que o anúncio de agravamento da saúde do paciente e do risco de morte passam por um trabalho consigo próprio. A autora explicita a importância da tomada de consciência de seus sentimentos por parte da equipe:

O membro da equipe de saúde está sujeito a uma forte tensão para conseguir mascarar seus sentimentos. É apenas o reconhecimento dessa tensão que lhe permitirá controlá-la. É apenas aceitando abaixar suas defesas - aceitando a própria vulnerabilidade - que ele poderá se adaptar a uma nova situação. Esta é a única maneira de esperar que as decisões 
sejam mais adaptadas às necessidades dos pacientes do que às dos cuidadores. (Séguret, 2013, p. 45 tradução nossa)

Os grupos de fala ajudam a equipe de saúde nas transformações da exepriência emocional. A capacidade de sonhar em grupo, de realizar trabalho psicológico, permitiu à equipe de saúde metabolizar acontecimentos dolorosos vividos. Quando esta forma de cuidar está ausente, “sofremos com a sobrecarga de experiências emocionais obscuras e perturbadoras" (Figueiredo, 2007, p. 18).

A atuação do psicólogo na UTI Neonatal permite a criação de um espaço para a equipe falar sobre a morte de um bebê e dos sentimentos, em especial o de impotência, gerados diante da morte. O sofrimento dos cuidadores diante da perda de um paciente é inevitável. Um espaço de contenção para os sentimentos dos cuidadores permite que eles continuem sonhando. As funções maternas de holding (Winnicott, 1975) e rêverie (Bion, 1962) podem ser exercidas pelo psicólogo da equipe e pelo próprio grupo.

A equipe de saúde, quando recebe o holding necessário para o desempenho de suas funções, estará em melhores condições de oferecer o holding aos pais do bebê internado que, por sua vez, poderão cuidar de seu bebê. Certa vez, no corredor da UTI Neonatal, uma mãe trazia seu bebê, João, para uma consulta de rotina com o chefe do serviço de Neonatologia. Ao encontrar a psicóloga do serviço, a mãe virou-se para seu bebê e reapresentou o bebê para a psicóloga e afirmou: "João, essa é a psicóloga aqui da UTI. Ela cuidou da mamãe para que a mamãe pudesse cuidar de você”. Acreditamos que essa frase pode ser estendida aos demais membros da equipe, que cuidaram dessa mãe para que ela pudesse cuidar de seu bebê.

É importante pensar que o psicólogo precisará, ele próprio, de um espaço de holding, contenção e rêverie e, para isso, a análise pessoal e a supervisão são fundamentais. A análise pessoal e a supervisão irão contribuir para que o psicólogo possa manter a boa distância das experiências vividas dentro da UTI Neonatal, permitindo que mantenha a sua capacidade de auxiliar a equipe. Além disso, há questões transferenciais e contratransferenciais que precisarão ser levadas em conta. É importante mencionar a troca com psicólogos de outros serviços de UTI Neonatal e o retorno para a vida acadêmica como também possuindo essa função de criar um espaço para pensar. 
O ambiente da UTI Neonatal diante das emoções intensas e da constante ameaça de morte pode ser ameaçador para a saúde psíquica do cuidador. O grupo de fala pode garantir um espaço reservado para o pensamento: "Possibilidade de manter reservas físicas, psíquicas e somáticas nesse contexto é fundamental para o funcionamento da unidade e para a saúde mental de todos os envolvidos" (Condes, 2012, p. 175).

O enquadre institucional para o grupo de fala é fundamental, na medida em que reconhece a importância de sustentar os profissionais para que possam exercer suas funções de cuidado e sustentação dos bebês e de seus pais.

\begin{abstract}
É oportuno enfatizar como todos os personagens desse cenário estão imersos em situações traumáticas constantes, em angustia e em desamparo, deparando com as mais diversas perdas e lutos, e quanto tais fenômenos afetam e, muitas vezes, comprometem sua capacidade de simbolizar as vivências. Efeitos nefastos nos níveis intrapsíquico e intersubjetivo podem ser presenciados quando há impossibilidade de manter o pensamento. Faz-se urgente que o psiquismo continue a funcionar; que os processos de simbolizar, de representar, de devanear não sejam abruptamente interrompidos pelo excesso - traumático - que rodeia a UTI neonatal. (Condes, 2012, p. 177)
\end{abstract}

Um espaço destinado à equipe expressar suas experiências, suas dificuldades em relação à alguma decisão, ou atos que lhes solicitam muito no plano emocional, parece ser fundamental. Esses encontros necessitam de um clima de confiança da equipe para que possa se expressar sem que haja julgamento (Soubieux, 2013).

Não se deve esquecer que a formação da equipe para lidar com situações difíceis permite que a equipe sustente os pais ao longo do caminho a ser percorrido na UTI Neonatal. Soubieux (2013) afirma que a organização de formação adaptada às necessidade é essencial: "essas formações serão úteis à condição que elas sejam acompanhadas de um pensamento sobre as práticas e que elas não se tornem 'pensamentos práticos a aplicar'” (p. 164). A autora adverte que condutas rígidas a seguir, desempenhadas por profissionais inadvertidos e legitimamente extenuados diante de pais traumatizados, podem trazer consequências nefastas sobre estes últimos e sobre as crianças.

Para que os profissionais encontrem um bom lugar junto aos pais dos bebês, eles próprios necessitam ser sustentados e trocar sobre suas experiências. Eles não podem permanecer isolados, e formações à respeito do acompanhamento psicológico das famílias podem oferecer um espaço de expressão e de reflexão. Sustentar e conter são funções essenciais no trabalho com os profisssionais para 
que as situações potencialmente traumáticas, vivenciadas pela equipe de UTI Neonatal ao lidar com os recém-nascidos não se tornassem "angústias impensáveis", devido ao caráter recorrente dos acontecimentos. Acreditamos que o holding também pode ter função de reestabelecer a capacidade de sonhar dos membros da equipe, para que possam elaborar as experiências emocionais vividas e exercer criativamente as suas funções. E seria esse mesmo holding, através de um grupo de fala, que permitiria à equipe perceber-se alvo das identificações projetivas dos pais e refletir sobre possíveis caminhos para auxiliá-los no delicado processo de se tornar pai e mãe de seu bebê.

\section{1}

\section{Pesadelos relacionados ao serviço}

Reanimação de um bebê, internação de outro bebê, cuidados com um terceiro bebê com inúmeras malformações, acompanhamento de outro bebê que está morrendo: todas essas situações podem acontecer durante um único dia de plantão. A equipe de saúde da UTI Neonatal está ali naquele ambiente enfrentando todas as situações que se apresentam. São casos emocionalmente impactantes, capazes de abalar as defesas psíquicas que os cuidadores saudavelmente precisam lançar mão para continuar desempenhando suas tarefas diárias.

No serviço de reanimação pediátrica em que trabalha Séguret (2013), há duas psicólogas: uma dedica-se ao suporte da equipe de saúde, enquanto a outra desenvolve um trabalho de apoio às famílias. Ao longo dos anos em que atuou como psicóloga dedicada exclusivamente à equipe de saúde do serviço de reanimação, Séguret (2013) surpreendeu-se com a frequência com que membros da equipe de saúde relatavam pesadelos relacionados à reanimação pediátrica $\mathrm{e}$ neonatal.

Ogden (2010) compreende os pesadelos como "sonhos ruins" que perturbam o sono:

Ao despertar, o sonhador é capaz, imediatamente, ou dentro de um período relativamente curto de tempo, de distinguir estar acordado de estar dormindo, o perceber e o sonhar, a realidade interna e a realidade externa. Consequentemente, o indivíduo muitas vezes é capaz de lembrar-se do conteúdo do pesadelo ao despertar e ser capaz de pensar e falar sobre ele. (p. 20) 
No "sonho ruim", o sofrimento emocional que acomete o indivíduo passa por uma elaboração inconsciente: "Entretanto, este sonhar é interrompido em um ponto onde a capacidade do indivíduo de gerar pensamentos-sonho e sonhá-los é sobrepujada pelos efeitos perturbadores da experiência emocional sendo sonhada" (Ogden, 2010, p. 20).

O trabalho de Séguret (2013) consistiu, em um primeiro tempo, empiricamente, em escutar os pesadelos contados pelos membros da equipe de saúde. Posteriormente, demandou aos cuidadores que haviam tido os pesadelos que escrevessem seus pesadelos, unicamente com o intuito de preservar os termos. A autora esclarece que nenhum tipo de interpretação foi feita. O seu papel é o de psicóloga da equipe de saúde e não de analista pessoal. Seu interesse estava em destacar as semelhanças e as invariáveis dos pesadelos de cuidadores do serviço de reanimação "confrontados nas mesmas cenas traumáticas de medo em que corpos abertos, sexos desnudos e morte estão expostos ao olhar" (Séguret, 2013, p. 46).

Sendo estreita a relação entre trauma e sonho, isso nos faz pensar justamente nos acontecimentos traumáticos, ou potencialmente traumáticos, a que está sujeita a equipe de saúde da UTI Neonatal e nos pesadelos que alguns membros relatam. Interrogamo-nos qual seria a função do pesadelo para os profissionais de saúde: seria uma compulsão à repetição? Tratar-se-ia de uma tentativa de elaboração da situação traumática?

Relembrando o exemplo de puncionar o acesso venoso de um bebê prematuro extremo, muitas vezes é necessário, momentaneamente, esquecer-se que se trata de um bebezinho para não vacilar no ato. É uma ação que requer precisão e a hesitação ou imprecisão do cuidador podem causar ainda mais dor no bebê. Assim, é interessante notar que, na hora da punção, o bebê fica oculto atrás de um campo cirúrgico, e ali, na imensidão do campo, só é possível ver um bracinho que se apresenta para ser puncionado.

Esta é uma cena descrita acima e corriqueira na UTI Neonatal e foi o ponto central do pesadelo relatado por um residente do serviço de reanimação pediátrica em que atua a psicóloga Sylvie Séguret:

$\mathrm{O}$ pesadelo do manequim vivo [A., residente]: Eu me lembro simplesmente que nós estávamos mais ou menos fazendo um curso para aprender diversos gestos médicos no manequim, depois eu creio ter dito que gostaria de aprender a dar injeção, tirar sangue simplesmente porque não aprendemos muito isso em medicina. Eu me debruço então 
sobre o braço do manequim, um falso braço em plástico com veias desenhadas em cima, e eu furo. Quando eu chego na veia falsa, eu me dou conta de repente que tem muito sangue e eu levanto a cabeça em direção ao rosto do manequim e eu vejo o rosto de uma menina que me olha muito amedrontada com grandes olhos e que geme. Eu me lembro de ter olhado para a minha direita, porque outras pessoas treinavam sobre o outro braço e me dizer "mas ninguém vê que é uma verdadeira menina", e lhes dizer em voz alta para que os outros parem mas ninguém me escuta e todo mundo continua a agulhar. (Séguret, 2013, p. 46, tradução nossa)

A morte na UTI Neonatal exposta diante de todos e a frequência com que ela ocorre no serviço podem ameaçar as defesas dos cuidadores. No pesadelo relatado por Nicolas, o cuidador associa seus pesadelos terríveis às mortes no serviço de reanimação pediátrica. Acreditamos que os pesadelos apresentados por Séguret (Séguret, Hubert \& Golse, 2012; Séguret, 2013), relacionados ao serviço da UTI Neonatal, corroboram o quão impactante é o ambiente a equipe de saúde.

O sonho de Nicolas: Eu não consigo mais dormir. Após as mortes, eu tenho pesadelos terríveis. O último pesadelo, eu estou doente. Sofro de uma gangrena no braço. Meu braço estava preto, necrosado. Eu sei que eu vou morrer, meu prognóstico vital é grave, não tenho mais do que poucos meses de vida. Minha família insiste para que eu me vá. Eles querem que eu vá embora, eu percebo que os membros de minha família não estão em condições de suportar, então eles me dizem para partir: "Você pode partir Nicolas, pronto, você pode partir, vá".

Eu sinto que eu sou um fardo para meus próximos. Mas eu não quero. Eu me agarro à vida e eu quero VIVER. Eu vejo que meus próximos não me aguentam nem a minha doença, mas eu me agarro à vida, eu amo a vida e eu não quero partir. Eu não quero morrer. No entanto, eu sei que a doença me ronda, e eu procuro passar o máximo de tempo com meus sobrinhos e sobrinhas. Eu me vejo sentado rodeado pelos filhos de meus irmãos e irmãs. Eu estou contente de estar rodeado dos pequenos que são tão importantes para mim. E apenas por eles, eu não quero partir.

Eu acordo sobressaltado. Eu estou em lágrimas, eu choro muito e eu levo alguns minutos para me dar conta que era apenas um pesadelo. Mas a emoção provocada por este sonho é tamanha que eu tenho dificuldade de parar de chorar. Eu me dou conta que a carga emocional do que eu vivo no serviço onde eu trabalho me submerge. Eu tenho consciência que eu sou eficaz no meu trabalho quotidianamente. Eu trabalho com eficácia, humanidade, profissionalismo. A relação de apoio que eu ofereço para as famílias é rica e os ajuda. Mas eu sinto que mais eu sou eficaz nos cuidados, mais minhas emoções são exacerbadas. Foi após ter vivido tudo isso que eu decidi encontrar com Sylvie a psicóloga do serviço para falar sobre isso. (Séguret, Hubert \& Golse, 2012, p. 593, tradução nossa)

O sonho de Nicolas lhe pareceu tão real que ele leva alguns minutos para dar-se conta de que se tratava de um pesadelo. O encontro de Nicolas com a psicóloga do serviço permitiu a Nicolas distanciar-se para compreender os sentimentos que vieram à tona em seu sonho. De acordo com Séguret (Séguret, Hubert \& Golse, 2012), o sonho de Nicolas explicitaria o desejo de morte algumas vezes manifestado pelos cuidadores ou pelos pais de pôr fim ao sofrimento da criança, mas também a seu próprio sofrimento, ainda que ao preço da morte da criança. 
É importante fazer a ressalva de que nenhuma interpretação é feita nos casos em que os cuidadores contam seus sonhos ou pesadelos à psicóloga do serviço:

\begin{abstract}
Não se trata de interpretar os sonhos, próprios a cada sonhador e dependentes de sua história pessoal e única. Mas a frequência dos temas interativos diretamente ligados à reanimação e ao que lá acontece nos alertou. Assim, a noção de inquietante estranhamento, a não diferenciação entre animado e inanimado, mas também a identificação à criança no momento de tomada de decisões éticas, o desejo de salvar e entregar uma criança viva à mãe, a dificuldade da relação com os pais, a frágil fronteira entre vida e morte em reanimação, etc. são experiências emocionais quotidianas em "rea" (reanimação) e merecem toda a nossa atenção durante a escuta dos cuidadores. (Séguret, Hubert \& Golse, 2012, p. 595, tradução nossa)
\end{abstract}

A demanda para que os pesadelos fossem escritos permitiu aos cuidadores um distanciamento inicial. Contá-los à psicóloga do serviço dedicada à equipe de cuidadores e poder falar sobre o pesadelo proporcionou um sentimento de apaziguamento, além de contribuir para a elaboração do conteúdo sonhado. Séguret (Séguret, Hubert \& Golse, 2012) lembra que, durante as trocas informais no serviço, ao relembrarem os pesadelos e contá-los aos demais, alguns membros da equipe percebiam que outros cuidadores também têm sonhos e pesadelos relacionados a situações angustiantes do serviço. Muitas vezes, esses relatos causavam crises de riso, que podem ser compreendidas com características defensivas e saudáveis ao mesmo tempo:

O alívio sentido pelos cuidadores após a verbalização dos sonhos, ou de situações emocionantes ou dramáticas nas encenações, permite uma elaboração psíquica dos conflitos internos e uma tomada de consciência maior dos mecanismos de defesa e dos movimentos projetivos de uns sobre os outros. (Séguret, Hubert \& Golse, 2012, p. 595, tradução nossa)

Acreditamos que a função do sonho seria uma abertura para a narratividade e, nesse sentido, o sonho só faz sentido quando compartilhado, tal como aconteceu com os sonhos transcritos acima ao serem contados para a psicóloga e para outros membros da equipe de saúde.

A narratividade do sonho permite que, ao repetir o sonho, o sujeito elabore o conteúdo sonhado. Trata-se de uma tentativa de ligar o trauma ao funcionamento do psiquismo. Contar o sonho traz sentido àquilo que o pesadelo tentou resolver: "uma situação complexa, próxima do real, com interrogações de ordem moral, sobre o que convém fazer" (Séguret, 2013, p. 47, tradução nossa). O compartilhamento do pesadelo permite a digestão psíquica entre o sonhador e aquele que o escuta, tornando-se assim uma construção metaforisante. 


\section{2}

\section{Caso Sara: uma narratividade coconstruída}

Neste ambiente de UTI Neonatal, em que a morte é uma ameaça constante, é necessário que a equipe possa se manter psiquicamente viva. Além dos grupos de fala apresentados acima, gostaríamos de nos debruçar sobre o filme "Sara, une narrativité collégiale: l'éthique au quotidien dans un service de réanimation pédiatrique" ("Sara, uma narratividade coconstruída: a ética no quotidiano de um serviço de reanimação pediátrica", tradução nossa), produzido por Séguret e dirigido por Jeudon (2016).

Sara esteve internada por quase um ano no serviço em que atuava Séguret. Ela nasceu com uma patologia rara e complexa, tendo sido internada no serviço de reanimação pediátrica com 1 mês de vida e falecido com 1 ano. Seus pais moravam longe, sua mãe precisava cuidar do irmão mais velho e, por isso, não conseguia ir com grande frequência ao serviço. Os cuidadores de Sara se apegaram muito a ela e não conseguiram debater, como normalmente era feito em relação aos demais pacientes, como seria conduzida a reanimação de Sara quando sua saúde se agravasse.

Um determinado dia a saúde de Sara se agravou, ela teve uma parada cardíaca, precisando ser reanimada. Era seu médico de referência que estava de plantão e, em conjunto com os demais membros da equipe que estavam no plantão, decidiram interromper a reanimação de Sara. Sara faleceu de madrugada, sem que seus pais conseguissem chegar a tempo. Uma das enfermeiras que estava presente a segurou nos braços.

Na manhã seguinte, a equipe que chegava para o plantão estava em choque e revoltada por não terem continuado a reanimação de Sara, sendo infrutífera a explicação sobre a decisão da equipe tomada durante o plantão. O peso da decisão de parar a reanimação de Sara havia recaído sobre poucos membros da equipe. A equipe havia se apegado muito a esta paciente e havia uma ambivalência muito grande em torno da decisão de não reanimá-la. A divisão da equipe em dois grupos, o primeiro composto pelos que tomaram a decisão de interromper a reanimação e o segundo pelos que não concordavam com a decisão, motivou uma 
reunião da equipe logo após o falecimento. Havia no serviço um clima bastante tenso e de incompreensão.

Durante a reunião de equipe foi possível falar sobre a decisão de não continuar a reanimação de Sara, a sua morte e todo o sofrimento da equipe diante de sua morte. A reunião durou mais de 2 horas. Ao final, tendo sido o encontro muito marcante para toda a equipe de saúde do serviço de reanimação pediátrica, Séguret lamentou não tê-la gravado em vídeo. A ideia de fazer um filme sobre esta experiência surgiu após a reunião com a equipe.

Durante a reunião de equipe foi possível dizer aos cuidadores que estavam de plantão no dia em que Sara faleceu, que todos estavam apoiando e solidários à decisão de não continuar a reanimação de Sara. Desta forma, o peso da decisão pode ser redistribuído entre os membros da equipe e não pesar exclusivamente nos ombros de poucos cuidadores.

Participaram do filme membros da equipe de saúde do serviço de reanimação pediátrica, que acompanharam Sara ao longo de sua internação e no momento de sua morte. O caso de Sara foi escolhido pois demandou emocionalmente os cuidadores individualmente e a equipe como um todo.

O filme foi projetado inúmeras vezes em reuniões de equipe para que todos, presentes ou ausentes no momento do falecimento de Sara, o pudessem assistir. A cada projeção do filme, os membros da equipe de saúde se emocionavam e muitos choravam. As projeções foram muito produtivas para as reuniões, uma vez que se tratava de uma situação extremamente complexa e que suscitava muitos questionamentos éticos e reflexão.

Acreditamos que a reunião de equipe após a morte de Sara, a produção e a reprodução do filme no serviço de reanimação pediátrica tenham tido a função de conter e de transformar os fortes sentimentos experimentados pelos membros da equipe. Nesse sentido, acreditamos que o filme "Sara" também teve função antitraumática no serviço de reanimação pediátrica, possibilitando um bom funcionamento psíquico e contribuindo para que os cuidadores superassem as dificuldades apresentadas.

As perguntas apresentadas por Séguret ao final do filme nos mostram que cada projeção poderá sempre suscitar novos questionamentos por parte dos cuidadores: "Qual teria sido o lugar ocupado por Sara na vida dos cuidadores? Qual lugar tiveram os cuidadores na vida de Sara? Houve muito investimento? 
Houve muita emoção? Como investir sem se esgotar? Como transformar sofrimento em reflexão?". Nesse sentido, acreditamos que a projeção do filme e as reuniões que se seguiram às projeções constituíram também espaços de reflexão com funções antitraumáticas, fundamentais neste tipo de serviço. Séguret conclui afirmando que o filme "representa um trabalho de sublimação, indispensável para permitir a cada cuidador de continuar a trabalhar, transformando a emoção compartilhada em reflexão transdisciplinar coletiva, refinando nossas práticas diárias" (Séguret \& Jeudon, 2016, tradução nossa).

O filme nos ajuda a pensar em quão impactante é a experiência de trabalhar em UTI Neonatal, em que há investimento emocional muito grande de cada cuidador e da equipe como um todo. O caso Sara é apenas um, dentre os muitos casos, que ganhou destaque, por ter sido muito tocante para a toda a equipe.

No entanto, propomos a seguinte reflexão: multiplique-se o número de casos semelhantes ao de Sara e que levam o bebê a óbito no decorrer de um ano no mesmo serviço. Fazendo este exercício, é impossível não pensar na contínua necessidade de cuidar da saúde psíquica da equipe. Lembremos também do exemplo citado por Séguret (2013), quando uma enfermeira, logo após a decisão de interromper a reanimação de uma criança, ao ser questionada pela psicóloga a respeito de qual seria a taxa de mortalidade do serviço, afirma que a taxa de mortalidade é de $80 \%$, quando em verdade a taxa é de $13 \%$. Acreditamos que a inversão destes números pela enfermeira nos ajuda a pensar o quão extenuante pode ser o trabalho em UTI Neonatal. Ainda que tenha sido "apenas uma" criança, a enfermeira sentia como se a maioria das crianças do serviço morresse.

Devemos destacar como a sustentação e a contenção emocional oferecidas pelo grupo é fundamental para o desempenho das funções. Os grupos de fala, como o grupo que ocorreu logo após a morte de Sara, permitem que a equipe de saúde possa transformar a experiência emocional. A capacidade de sonhar em grupo, de realizar trabalho psicológico, é o que possibilita à equipe de saúde metabolizar acontecimentos dolorosos vividos, tais como a morte de Sara.

Nesse sentido, é importante destacar a atuação do psicólogo na UTI Neonatal, garantindo a criação de um espaço para a equipe pensar e falar sobre a morte e dos sentimentos, nomeadamente o de impotência, que inevitavelmente surge diante da morte. O sofrimento dos cuidadores provocado pela perda de um 
paciente é inevitável. Acreditamos ser fundamental um espaço de contenção para os sentimentos dos cuidadores, permitindo que eles continuem sonhando. 


\section{5 \\ Considerações finais}

Ao longo do presente trabalho procuramos demonstrar como o ambiente de UTI Neonatal é um ambiente de excessos de barulhos, de apitos, de luzes, de estímulos. Diante da fragilidade do bebê, o desamparo dos pais fica evidente. Ao terem seu bebê encaminhado para a UTI Neonatal, os pais podem viver um momento de caos psíquico. Mecanismos muitos arcaicos, como a identificação projetiva, são formas de defesas das quais os pais podem lançar mão. Defendemos a ideia de que o ambiente da UTI Neonatal pode ter características potencialmente traumáticas, inclusive para a equipe de saúde que cuida dos bebês frágeis e em risco de morte. Por cuidarem de bebês muito vulneráveis, há sempre um fantasma de morte que assombra a equipe. Todos os esforços dos cuidadores e o avanço da tecnologia não garantem a sobrevivência dos bebês.

Concordamos com a concepção de Séguret (2013), ao afirmar que o trabalho em UTI Neonatal possui todos os ingredientes de um drama clássico: um drama divido em atos, após os quais nenhum de seus atores será mais o mesmo; e, no centro da cena, um bebê em risco de morte. Esta descrição nos ajuda a compreender o quão impactante psiquicamente pode ser o trabalho em UTI Neonatal para a equipe de saúde.

O contexto da UTI Neonatal acentua as condições de desamparo de todos os atores envolvidos: bebês, pais e, inclusive, da equipe de saúde. A equipe, identificando-se com o desamparo inicial do bebê, precisará lançar mão de algumas defesas para continuar desempenhando suas funções. Assim, nesse sentido, as defesas possuem caráter positivo. Produzidas em excesso, as defesas possuiriam caráter negativo, pois produziriam anestesiamento afetivo.

Abordamos o conceito de trauma a partir das teorias de Ferenczi (1933/2011) e Winnicott (1963b), por compreendermos o trauma como algo excessivo e potencialmente desestruturante para o psiquismo. Acreditamos que o ambiente da UTI Neonatal é um ambiente de excessos que, por aproximar dois eventos importantes da vida, o nascimento e a morte, pode abalar o psiquismo dos cuidadores. Além disso, os autores enfatizam a importância relacional para a manutenção da saúde psíquica do sujeito. A presença implicada do outro é 
fundamental quando pensamos em termos de constituição psíquica, mas também ao longo da existência do sujeito, em especial em ambientes como o da UTI Neonatal.

Utilizamos a teoria ferencziana sobre a confusão de línguas (Ferenczi, 1933/2011) para destacar a racionalidade do discurso adulto da equipe de saúde de UTI Neonatal, promovendo um distanciamento do que está ligado aos afetos e às emoções. Acreditamos que, para cuidar de bebês, assim como acontece com as mães, é necessário que equipe de saúde se identifique com eles, entrando em contato com suas partes mais arcaicas.

Diante da constante ameaça de morte dos bebês internados em UTI Neoantal e a partir do que Ferenczi descreve sobre o "bebê sábio" (Ferenczi, 1933/1992), propusemos a ideia da “equipe sábia”, que, com um discurso racional, se afastaria das suas partes frágeis e vulneráveis. Sem dar testemunho do seu sofrimento, acreditamos que o desamparo da equipe é ainda maior.

Consideramos que dar voz ao discurso bebê da equipe de saúde, em grupos de fala, contando com a presença implicada de um outro, é uma das possibilidades de contenção e sustentação emocional dos cuidadores. Encontrando um ambiente acolhedor, é possível fazer sentido do que se vive na UTI Neonatal.

Procuramos destacar a importância da presença da psicóloga em UTI Neonatal oferecendo sustentação, não apenas para os pais dos bebês internados, mas também para a equipe de saúde. Muitas vezes, como é o caso da instituição em que atuamos, o trabalho de sustentação é um trabalho de corredor, de interstício (Séguret, 2013), e acontecerá de acordo com a demanda de cada cuidador. Ainda que hoje não seja possível ter uma psicóloga que se dedique exclusivamente ao atendimento da equipe de saúde, como defende Séguret e como ocorre em seu serviço de reanimação pediátrica, seguimos confiantes.

Raiva, tristeza e angústia são sentimentos recorrentes em pais que têm seus bebês internados em UTI Neonatal. Com seus recursos psíquicos abalados, os pais podem lançar mão de mecanismos de defesas primitivos, tais como a identificação projetiva (Klein, 1946/1991a), para se defender. Identificação projetiva foi um conceito primeiramente desenvolvido por Klein (1946/1991a) e posteriormente ampliado por Bion (1962), compreendendo a identificação projetiva como modo de comunicação primitiva. Tal conceito ajudou-nos a compreender o que se passa entre pais e equipe de saúde. Ser alvo da identificação projetiva parental pode 
contribuir para tornar o atendimento das famílias ainda mais complexo, pois exige habilidade da equipe para lidar com as projeções.

Vivendo um momento de caos psíquico e tendo sua capacidade de pensar afetada devido à vulnerabilidade de seu bebê na UTI Neonatal, os pais projetariam seus sentimentos de raiva, de tristeza e de angústia, com os quais não estão conseguindo lidar, na equipe de saúde. A identificação projetiva neste caso serviria ao mesmo tempo de defesa para os pais e como forma de comunicação primitiva.

Utilizamos a metáfora continente-conteúdo bioniana para compreender o processo da identificação projetiva. A equipe de saúde (equipe-receptora) serviria de continente para os sentimentos projetados (elementos brutos) pelos pais, metabolizando-os e, posteriormente, devolvendo-os (elementos alfa) aos pais para reintrojeção através das interações pais-equipe de saúde. Através da capacidade de rêverie da equipe, a equipe de saúde pode receber a identificação projetiva dos pais, seja ela boa ou má, transformando os elementos beta em elementos alfa (Bion, 1962).

Ocorre que, neste ambiente já carregado de tensão, perceber-se alvo da identificação projetiva dos pais nem sempre é fácil, somando-se a isso a capacidade de manejo da identificação projetiva. Nesta perspectiva, podemos pensar que, para a equipe de saúde da UTI Neonatal, perceber-se receptora da identificação projetiva dos pais pode ser extremamente difícil. Cada membro da equipe possui uma história pessoal, que não pode ser ignorada. Este processamento psicológico da identificação projetiva pelo receptor pode ser incompleto e contaminado pela patologia do receptor. Esses são pontos muito delicados e, ao mesmo tempo, essenciais para o acolhimento dos pais dos bebês no serviço.

O manejo suficientemente bom da identificação projetiva passa pela aceitação de seus próprios sentimentos. Não podemos esquecer que os membros da equipe de saúde são sujeitos, com suas histórias pessoais. Os sentimentos com os quais os pais dos bebês internados precisam lidar podem ser difíceis e com grande carga emocional para os cuidadores também.

Para que os pais possam receber sustentação e continência por parte da equipe de saúde da UTI Neonatal, é fundamental refletir sobre a sustentação e a continência recebida pela equipe para o desempenho de suas funções. Para o 
manejo suficientemente bom da identificação projetiva dos pais, a equipe deve ser capaz de lidar com seus próprios sentimentos hostis e de destrutividade, que estão presentes em todos os tipos de relação.

Nesse sentido, procuramos refletir sobre sustentação e acolhimento dos aspectos emocionais da equipe de saúde. O holding e a contenção, aspectos antitraumáticos da função materna, promovem estabilidade mental e ligações importantes para a saúde psíquica do sujeito.

Diante das intempéries da vida, e a UTI Neonatal está cheia delas, o sujeito precisa "fazer sentido" (Figueiredo, 2007) sobre as dificuldades enfrentadas. O holding proporciona o sentimento de continuidade de existência, isto é, a experiência de sentir-se vivo. Enquanto a contenção garante experiências de transformação, de crescimento e de expansão.

Tanto no holding como na contenção é necessária a presença implicada do outro. Na UTI Neonatal, a necessidade da presença implicada do outro fica evidente diante do desamparo do profissional que acompanha bebês em risco de morte. A equipe de saúde precisa elaborar as vivências emocionais, realizar trabalho psicológico através do ato de sonhar (Bion, 1962).

Em um ambiente de excessos traumáticos e ameaças de sem-sentido, é importante dar tempo e espaço para que as fantasias inconscientes do sujeito possam emergir. Séguret (2013) denomina este espaço de "hora de pausa" e Mathelin (1999) de "reunião de síntese". Nós nos propusemos a chamá-lo de "grupo de fala". Inspirado pelo modelo apresentado pelas autoras francesas, um grupo de fala poderia ter periodicidade semanal, sendo coordenado por uma psicóloga. Trata-se de um espaço de sustentação e de contenção para a equipe de saúde.

Através das trocas promovidas pelo grupo, é possível "fazer sentido" dos acontecimentos ocorridos dentro da UTI Neonatal. No grupo de fala é possível que os cuidadores metabolizem os sentimentos dolorosos que emergem a partir dos acontecimentos. A coconstrução de uma narratividade para os acontecimentos do serviço nos parece ser fundamental para a manutenção da capacidade de pensar da equipe. Procuramos ilustrar a coconstrução de uma narrativa através do filme “Sara", produzido por Séguret e dirigido por Jeudon (2016).

Os grupos de fala da equipe de saúde são um local de troca com função de espaço potencial em que os membros da equipe podem pensar sobre os 
acontecimentos do serviço, já que no dia a dia é difícil parar em uma UTI Neonatal. São espaços fundamentais em serviços onde a angústia e a violência predominam em razão da gravidade das situações. Um espaço reservado à expressão e ao reconhecimento dos afetos, das projeções e das angústias dos cuidadores garante, em nosso entendimento, o reconhecimento da humanidade das crianças, mas também dos membros da equipe de saúde.

A psicóloga da equipe tem o papel de favorecer a circulação da palavra, atenuando as tensões subjacentes, graças a sua escuta atenta e a sua função de receptáculo de angústias (Soubieux, 2013). Os grupos de fala possibilitam que a equipe compreenda os processos arcaicos, em jogo em ambientes como o da UTI Neonatal. Nesses grupos, permite-se a criação de um aparelho de pensar comum e, consequentemente, um apaziguamento das tensões psíquicas (Séguret, 2013).

Acreditamos que o grupo de fala também permitiria o reconhecimento da ambivalência da equipe de saúde em relação aos bebês internados no serviço. Relembrando o que disse Golse (2003), não há como a equipe de profissionais se ocupar de um bebê sem ambivalência, pois um bebê "não é um todo rosa bombom". Não haveria razões para a equipe de saúde odiar os bebês internados? Eles apontam para a nossa fragilidade humana e para a nossa própria finitude. Malgrado a evolução tecnológica, alguns bebês não respondem ao tratamento conforme o esperado e teimam em morrer.

A atuação da psicóloga em UTI Neonatal permite a criação do grupo de fala e que se entre em contato com os sentimentos que surgem ao cuidar de bebês tão frágeis e também quando morre um bebê no serviço. Acreditamos ser necessário falar da morte para que a morte psíquica não prevaleça sobre a morte do corpo. 


\section{6 Referências bibliográficas}

Agman, M; Druon, C; Frichet. (1999). Intervenções psicológicas em neonatologia. In D. B. Wanderley (Org.), Agora eu era o rei: os entraves da prematuridade (pp. 17-34). Salvador, BA: Ágalma.

Alvarez, L.; Yamgnane, A.; Parat, S.; Benachi, A.; Vion, E.; Dugué, C.; Beauquier-Maccotta, B. \& Simas, R. (2012). Maternité. In P. Canoui, B. Golse \& S. Séguret (orgs.), La pédopsychiatrie de liaison: l'hôpital Necker au quotidien (pp. 97-141). Toulouse: Éditions Érés.

Bion, W. (1962). Learning from experience. In: W. Bion, Seven servants: four works. New York: New Ed.

Cintra, E. M. U. (2003). As funções antitraumáticas do objeto primário: holding, continência e rêverie. Tempo Psicanalítico, 35, 37-55.

Condes, R. P. (2012). Pensando o impensável: intervenções do psicólogo de base psicanalítica em Unidade de Terapia Intensiva Neonatal. (Dissertação de Mestrado). Pontifícia Universidade Católica de São Paulo, Programa de Estudos Pós-Graduados em Psicologia, São Paulo. Recuperado de https://tede2.pucsp.br/handle/handle/15130.

Davis, M. (1982). Limite e espaço: uma introdução à obra de D. W. Winnicott. Rio de Janeiro: Imago.

De Wailly, D. (2014). Les soignants et l'accueil de la mort périnatale: entre angoisse et anticipation. Le Carnet Psy, 185(9), 49-53. Recuperado de https://www.cairn.info/revue-le-carnet-psy-2014-9-page-49.htm.

Druon, C. (1999). Ajuda ao bebê e aos seus pais em terapia intensiva neonatal. In D. B. Wanderley (org.), Agora eu era o rei: os entraves da prematuridade. Salvador: Álgama.

Ferenczi, S. (2011). Confusão de língua entre os adultos e a criança (A linguagem da ternura e da paixão). In S. Ferenczi, Psicanálise IV (Obras completas, 4, trad. Á. Cabral, pp. 111-121). São Paulo: WMF Martins Fontes. (Trabalho original publicado em 1933).

Figueiredo, L. C. (2007). A metapsicologia do cuidado. Psyche, 11(21), 13-30. Recuperado de http://pepsic.bvsalud.org/pdf/psyche/v11n21/v11n21a02.pdf.

Fogaça, M. C.; Carvalho, W. B.; Cítero, V. A. \& Nogueira-Martins, L. A. (2008). Fatores que tornam estressante o trabalho de médicos e enfermeiros em terapia intensiva pediátrica e neonatal: estudo de revisão bibliográfica. Revista Brasileira de Terapia Intensiva, 20(3), 261-266. doi: 10.1590/S0103-507X2008000300009. 
Freud, S. (2010). Além do princípio do prazer. In S. Freud, História de uma neurose infantil ("O homem dos lobos"), além do princípio do prazer e outros textos (Obras completas, 14, trad. P. C. Souza, pp. 161-239). São Paulo: Companhia das Letras. (Trabalho original publicado em 1920).

Freud, S. (2012). Totem e tabu. In S. Freud, Totem e tabu, contribuição à história do movimento psicanalítico e outros textos (Obras completas, 11, trad. P. C. Souza, pp. 13-244). São Paulo: Companhia das Letras. (Trabalho original publicado em 1912-1913).

Gibeault, A. (2000). De la projection et de l'identification projective. Revue Française de Psychanalyse, 64(3), 723-742.

Golse, B. (2003). O bebê hoje: novos dados, esperanças e frustações. In C. M. F. Rohenkohl (org.), Sobre a psicoterapia pais-bebê: narratividade, filiação e transmissão (pp. 13-43). São Paulo: Casa do Psicólogo.

Klein, M. (1991a). Notas sobre alguns mecanismos esquizoides. In M.

Klein, Inveja e gratidão e outros trabalhos (Obras Completas de Melanie Klein, 3, pp. 20-43). Rio de Janeiro: Imago. (Trabalho original publicado em 1946).

Klein, M. (1991b). Nosso mundo adulto e suas raízes na infância. In M. Klein, Inveja e gratidão e outros trabalhos (Obras Completas de Melanie Klein, 3, pp. 280-297). Rio de Janeiro: Imago. (Trabalho original publicado em 1959).

Lejarraga, A. L. (2008). Clínica do trauma em Ferenczi e Winnicott. Natureza humana, 10(2), 115-147. Recuperado de http://pepsic.bvsalud.org/pdf/nh/v10n2/ v10n2a05.pdf

Mathelin, C. (1999). O sorriso da Gioconda: clínica psicanalítica com os bebês prematuros. Rio de Janeiro: Companhia de Freud.

Monteiro, J. K. (2012). Sofrimento psíquico de trabalhadores de unidade de terapia intensiva. Revista Psicologia, Organizações e Trabalho, 12(2), 245-250. Recuperado de http://pepsic.bvsalud.org/pdf/rpot/v12n2/v12n2a09.pdf.

Moraes, C. J. A. \& Granato, T. M. M. (2014). Narrativas de uma equipe de enfermagem diante da iminência da morte. Psico, 45(4), 475-484. Recuperado de $\mathrm{http}: / /$ revistaseletronicas.pucrs.br/ojs/index.php/revistapsico/article/view/15571/1 2474.

Morsch, D. S. \& Braga, M. C. A. (2007). À procura de um encontro perdido: o papel da "preocupação médico-primária" em UTI neonatal. Revista Latinoamericana de Psicopatologia Fundamental, 10(4), 624-636. doi: 10.1590/S1415-47142007000400005.

Ogden, T. (2010). Esta arte da psicanálise. Porto Alegre: Artmed.

Rabello, A. (2004). A função simbólica da UTI neonatal. In R. O. Aragão (org.), O bebê, o corpo e a linguagem (pp. 177-189). São Paulo: Casa do Psicólogo. 
Rudge, A. M. (2009). Trauma. Rio de Janeiro: Jorge Zahar.

Séguret, S.; Hubert, P. \& Golse, B. (2012). Analyse des pratiques en réanimation pédiatrique: travail d'une psychologue dédiée à l'équipe soignante. La psychiatrie de l'enfant, 55(2), 575-605. Recuperado de https://www.cairn.info/revue-lapsychiatrie-de-1-enfant-2012-2-page-575.htm.

Séguret, S. (2013). Du côte des soignants. Le Carnet PSY, 175(8), 45-47.

Recuperado de https://www.cairn.info/revue-le-carnet-psy-2013-8-page-45.htm.

Séguret, S. (Produção) \& Jeudon, X. (Direção). (2016). Sara, une narrativité collégiale: l'éthique au quotidien dans un service de réanimation pédiatrique [Filme cinematográfico]. França: Psynem. Recuperado de http://www.psynem.org/Perinatalite/Clinique_et_concepts/Ethique/Sara_narrativit e_collegiale.

Soubieux, M.-J. (2013). Le berceau vide: deuil périnatal et travail du psychanalyste. Paris: Éditions Érès.

Souza, O. (2003). Trauma, defesa e criatividade. Tempo Psicanalítico, 35, p. 115135.

Winnicott, D. W. (1960). Teoria do relacionamento paterno-infantil. In D. W. Winnicott, O ambiente e os processos de maturação (pp.38-54). Porto Alegre: Artmed.

Winnicott, D. W. (1963a). Da dependência à independência no desenvolvimento do indivíduo. In D. W. Winnicott, O ambiente e os processos de maturação (pp. 79-87). Porto Alegre: Artmed.

Winnicott, D. W. (1963b). O medo do colapso (Breakdown). In D. W. Winnicott, Explorações psicanalíticas (pp. 70-76). Porto Alegre: Artmed.

Winnicott, D. W. (1964). The child, the family and the outside world. Nova York: Perseus Publishing.

Winnicott, D. W. (1975). O brincar e a realidade. Rio de Janeiro: Imago.

Winnicott, D. W. (2000a). O ódio na contratransferência. In D. W. Winnicott, Da Pediatria à Psicanálise: obras escolhidas. Rio de Janeiro: Imago. (Trabalho original publicado em 1947).

Winnicott, D. W. (2000b). A preocupação materna primária. In D. W. Winnicott, Da Pediatria à Psicanálise: obras escolhidas. Rio de Janeiro: Imago. (Trabalho original publicado em 1956).

Zornig, S. (2010). Reflexões sobre uma ética do cuidado na primeira infância. Cadernos do CPRJ, 1(1), 15-26. Recuperado de http://www.cprj.com.br/ primordios/15-26_reflexoes.pdf. 
Zornig, S. A.-J.; Morsch, D. S. \& Braga, N. A. (2004). Os tempos da prematuridade. Revista Latinoamericana de Psicopatologia Fundamental, 7(4), 135-143. doi: 10.1590/1415-47142004004009. 